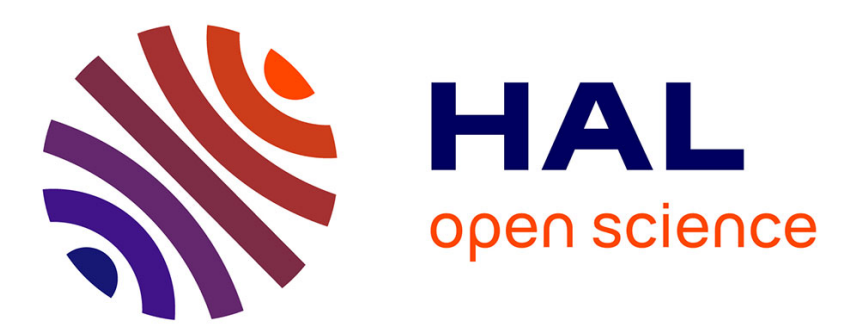

\title{
Threshold of motion and settling velocities of mollusc shell debris: Influence of faunal composition
}

\author{
Alissia Rieux, Pierre Weill, Dominique Mouazé, Clément Poirier, Farid
} Nechenache, Laurent Perez, Bernadette Tessier

\section{- To cite this version:}

Alissia Rieux, Pierre Weill, Dominique Mouazé, Clément Poirier, Farid Nechenache, et al.. Threshold of motion and settling velocities of mollusc shell debris: Influence of faunal composition. Sedimentology, 2019, 66 (3), pp.895-916. 10.1111/sed.12521 . hal-01897637

\section{HAL Id: hal-01897637}

\section{https://hal-normandie-univ.archives-ouvertes.fr/hal-01897637}

Submitted on 22 Dec 2020

HAL is a multi-disciplinary open access archive for the deposit and dissemination of scientific research documents, whether they are published or not. The documents may come from teaching and research institutions in France or abroad, or from public or private research centers.
L'archive ouverte pluridisciplinaire HAL, est destinée au dépôt et à la diffusion de documents scientifiques de niveau recherche, publiés ou non, émanant des établissements d'enseignement et de recherche français ou étrangers, des laboratoires publics ou privés. 


\title{
Threshold of motion and settling velocities of mollusc shell debris: Influence of faunal composition
}

\author{
ALISSIA RIEUX (D, PIERRE WEILL ID, DOMINIQUE MOUAZE (D, CLEMENT \\ POIRIER (D, FARID NECHENACHE, LAURENT PEREZ and BERNADETTE TESSIER \\ Normandie Univ, UNICAEN, UNIROUEN, CNRS, M2C, 14000 Caen, France \\ (E-mail: alissia.rieux@unicaen.fr) \\ Associate Editor - Subhasish Dey
}

\begin{abstract}
Bioclastic particles derived from mollusc shell debris can represent a significant fraction of sandy to gravelly sediments in temperate and cool-water regions with high carbonate productivity. Their reworking and subsequent transport and deposition by waves and currents is highly dependent on the shape and density of the particles. In this study, the hydrodynamic behaviour of shell debris produced by eight mollusc species is investigated for several grain sizes in terms of settling velocity (measurements in a settling tube) and threshold of motion under unidirectional current (flume experiments using an acoustic profiler). Consistent interspecific differences in settling velocity and critical bed shear stress are found, related to differences in shell density, shell structure imaged by scanning electron microscopy and grain shape. Drag coefficients are proposed for each mollusc species, based on an interpolation of settling velocity data. Depending on the shell species, the critical bed shear stress values obtained for bioclastic particles fall within or slightly below empirical envelopes established for siliciclastic particles, despite very low settling velocity values. The results suggest that settling velocity, often used to describe the entrainment of sediment particles through the equivalent diameter, is not a suitable parameter to predict the initiation of motion of shell debris. The influence of the flat shape of bioclastic particles on the initiation of motion under oscillatory flows and during bedload and saltation transport is yet to be elucidated.
\end{abstract}

Keywords Bioclastic sand, critical bed shear stress, flume experiments, scanning electron microscopy images (SEM), shell density, unidirectional flow.

\section{INTRODUCTION}

Understanding sediment hydrodynamic behaviour is necessary in order to refine interpretations of depositional environments in the fossil record, and to improve predictive numerical models for coastal zone evolution and management. The hydrodynamic behaviour of sediment particles is generally characterized experimentally by the measurement of two parameters: (i) the threshold of motion, which corresponds to the initiation of bed erosion; and (ii) the settling velocity, which is somehow related to the behaviour of the moving particle in the flow. Numerous studies have investigated the entrainment threshold of sediment particles in flume experiments since the pioneering work of Shields (1936), dedicated to natural sands and gravels, quartz grains, heavy minerals, glass beads or plastic particles. Reviews of these data can be found in Miller et al. (1977), Paphitis (2001) and Simões (2014). These studies led to the establishment of empirical Shields-type curves relating the dimensionless threshold shear stress of a 
particle to a dimensionless form of its diameter (grain Reynolds number). Significant dispersion of data around the empirical curves led these authors to propose threshold envelopes rather than threshold curves (Paphitis, 2001) to account for the irregular shape of natural particles, for uncertainties in the definition of the threshold of motion, or for the stochastic nature of turbulence and erosion processes. In contrast to siliciclastic sediment, few studies have investigated the entrainment conditions of bioclastic particles. Such studies are of great importance because carbonate sediments often prevail in tropical and temperate coastal regions, both in modern and fossil environments, and because bioclastic particles show a large diversity of shapes compared to the sub-rounded particles found in most detrital sands. Experiments by Prager et al. (1996) showed that critical shear stress values of biogenic sands derived from reef environments are smaller than those of classic quartz sand owing to particle shape and density. Smith \& Cheung (2004) found that thresholds of motion of coral sands lie above the Shields curve for hydraulically smooth flow, and below it for hydraulically rough flows. Compared to the sieve diameter, the equivalent particle diameter, derived from the particle settling velocity, appears to be a relevant parameter to describe more accurately the hydrodynamic behaviour of tropical to sub-tropical carbonate sediments (Kench \& McLean, 1996; Smith \& Cheung, 2004; Jorry et al., 2006; Flemming, 2017). Cool-water carbonates have been far less studied than their warm water counterparts (James \& Clarke, 1997). In these environments, bioclastic sediments are mainly composed of mollusc (bivalves and gastropods) skeletal remains (Kidwell, 2013), or are less frequently composed of coralline algae (Joshi et al., 2014, 2017), bryozoans or crustaceans.

Paphitis et al. (2002) investigated the entrainment threshold of cockle and mussel shell debris with sieve sizes ranging between $0.3 \mathrm{~mm}$ and $0.8 \mathrm{~mm}$. These authors showed that prediction of the entrainment threshold of such sediment is significantly improved when the movability number and the equivalent diameter are preferred to the Shields parameter and the sieve diameter. It also appeared that the two investigated species showed non-negligible differences in threshold of motion. For larger shell debris, Weill et al. (2010) suggested that the equivalent diameter is not the proper length-scale to consider the entrainment threshold. Indeed, the very flat shape of the bioclastic particles, resulting in low settling velocity values, also promotes stability and armouring when arranged in a sediment bed.

Settling velocity is another essential parameter for understanding sediment hydrodynamic behaviour, because it strongly influences the transport, deposition and sorting of particles. Early studies involved glass spheres falling freely in a viscous fluid, and suggested empiric equations that relate the particle diameter to its free fall velocity (Stokes, 1851; Oseen, 1927; Rubey, 1933; Janke, 1965; Gibbs et al., 1971; Van Rijn, 1993). Influence of particle shape on settling velocity was first investigated using artificial particles of various densities (McNown \& Malaika, 1950; Komar \& Reimers, 1978; Field et al., 1997). Maiklem (1968) was the first to investigate the settling behaviour of bioclastic carbonate grains and showed that, while the particle shape mainly controls the settling trajectory, settling velocity is also dependent on the bulk density, the size and the angularity of the particle. Braithwaite (1973) performed a similar study on carbonate sand derived from reef environments and defined four fall regimes, including straight fall, spinning, spiral mode and unstable spiral mode. Settling behaviour of tropical biogenic sand was further investigated by Kench \& McLean (1996). For cool-water carbonates, a more restricted number of studies was reported, including whole bivalve shells (Allen, 1984), shell fragments (Paphitis et al., 2002; Weill et al., 2010) and coralline algae (Joshi et al., 2014). Additionally, settling velocity of fossil foraminifera was reported and used to interpret past depositional environments (Jorry et al., 2006). Many studies used settling velocity to derive a better estimation of the grain size. Settling velocity may be used as an alternative to the particle sieve diameter, through the equivalent settling diameter. Indeed, apart from the size parameter, settling velocity integrates particle properties such as shape, roughness and density that are important in the overall hydrodynamic behaviour. This is especially true when particle shape differs strongly from a sphere, as with bioclastic particles. Differences of particle sizes derived from sieve and settling analyses have been investigated for different natural sands (Sengupta \& Veenstra, 1968; Komar \& Cui, 1984; Smith \& Cheung, 2002, 2003) and used to re-interpret the energy of depositional environments (Kench \& McLean, 1996, 1997; Flemming, 2017). Finally, some authors recommended the use of the equivalent settling diameter (or the settling velocity) to better predict the initiation 
of motion of sediment particles (Collins \& Rigler, 1982; Paphitis et al., 2002). However, Weill et al. (2010) showed that settling diameter is not a suitable parameter to predict the threshold of motion of coarse bioclastic particles because fragments show a good resistance to the flow when structured in a bed, despite small settling velocities.

Communities of benthic molluscs and other carbonate-producing marine organisms can vary spatially at a regional scale, depending on the sediment substrate, the food supply and the hydrodynamic conditions (Thorson, 1957; Holme, 1961; Beukema et al., 1983; Thorin et al., 2001). Modern assemblages are subjected to change in time as a consequence of climate fluctuations as well as anthropogenic activities (Hewitt et al., 2016). The development of shellfish farming and the introduction of nonindigenous species can cause drastic changes in the local benthic communities (Halpern et al., 2008). Spatio-temporal variability in diversity and structure of mollusc communities, in which species have different shell structure and composition, should therefore have an effect on the composition of mixed silici-bioclastic sediments, and thus on the hydraulic behaviour of biogenic particles produced by these living organisms.

The aim of this study is to investigate whether bioclastic particles produced by different mollusc species show significant differences in terms of settling velocity and threshold of motion. Whole shells from eight molluscs representative of temperate coastal regions were sampled in MontSaint-Michel Bay (France), crushed and sieved into size fractions. Settling velocities were determined in a settling tube and entrainment thresholds were measured in a current flume. Settling experiments are reported in terms of settling velocity and drag coefficient for the different mollusc species and the different sieve sizes. The entrainment thresholds measured are compared with existing threshold curves, and a discussion on the relationships between settling velocity and critical shear stress is initiated.

\section{METHODOLOGY}

\section{Sediment sampling and analysis}

The sedimentary material investigated in this study consists of mono-specific and mono-size bioclastic sand. Whole shells were collected on the southern coast of Mont-Saint-Michel Bay (Brittany, France) which is bordered by coarse, shelly chenier ridges (Bonnot-Courtois et al., 2004; Weill et al., 2012, 2013). Eight species of mollusc representative of the faunal composition of the area (Thorin et al., 2001) were selected (Table 1; Fig. 1), including five wild (Cerastoderma edule, Scrobicularia plana, Anomia ephippium, Ostrea edulis and Ruditapes philippinarum), two reared (Magallana gigas and Mytilus edulis) and one non-indigenous species (Crepidula fornicata).

Shells were sorted, washed with tap water, oven-dried at $40^{\circ} \mathrm{C}$, and broken with a hammer. Fragments were sieved into seven individual size fractions in a vibrating column for settling experiments; size fractions included: 0.63 to $1.0 \mathrm{~mm} ; 1.0$ to $2.0 \mathrm{~mm} ; 2.0$ to $3.0 \mathrm{~mm} ; 3.0$ to

Table 1. Common and Latin names of mollusc species used in this study, shell mineralogy and average shell density determined with a pycnometer.

\begin{tabular}{|c|c|c|c|}
\hline Latin name & $\begin{array}{l}\text { Common } \\
\text { name }\end{array}$ & $\begin{array}{l}\text { Shell } \\
\text { mineralogy }\end{array}$ & $\begin{array}{l}\text { Average } \\
\text { density } \\
\left(\mathrm{kg} \mathrm{m}^{-3}\right) \\
\rho_{s}\end{array}$ \\
\hline $\begin{array}{l}\text { Crepidula } \\
\text { fornicata }\end{array}$ & $\begin{array}{l}\text { Slipper } \\
\text { limpet }\end{array}$ & Aragonite & $2800 \pm 28 \cdot 6$ \\
\hline $\begin{array}{l}\text { Scrobicularia } \\
\text { plana }\end{array}$ & $\begin{array}{l}\text { Peppery } \\
\text { furrow } \\
\text { shell }\end{array}$ & Aragonite & $2781 \pm 35 \cdot 0$ \\
\hline $\begin{array}{l}\text { Cerastoderma } \\
\text { edule }\end{array}$ & Cockle & Aragonite & $2771 \pm 31 \cdot 1$ \\
\hline Ruditapes sp & $\begin{array}{l}\text { Manila } \\
\text { clam }\end{array}$ & Aragonite & $2754 \pm 30 \cdot 8$ \\
\hline Mytilus edulis & Mussel & $\begin{array}{l}\text { Calcite/ } \\
\text { aragonite }\end{array}$ & $2663 \pm 37 \cdot 4$ \\
\hline $\begin{array}{l}\text { Anomia } \\
\text { aphippium }\end{array}$ & $\begin{array}{l}\text { Saddle } \\
\text { oyster }\end{array}$ & Calcite & $2629 \pm 68 \cdot 8$ \\
\hline $\begin{array}{l}\text { Magallana } \\
\text { gigas }\end{array}$ & $\begin{array}{l}\text { Japanese } \\
\text { oyster }\end{array}$ & Calcite & $2081 \pm 29 \cdot 8$ \\
\hline Ostrea edulis & Flat oyster & Calcite & $2013 \pm 33 \cdot 4$ \\
\hline
\end{tabular}

Average density is measured on dry debris. In the case of oysters made of chalky calcite interstratified with foliated calcite, reported data are mean density values measured regardless of the type of calcite. Density values of each type of calcite structure were measured independently. Because values between oyster species are similar, mean values per calcite structure are reported; foliated calcite: $2478 \pm 58.8 \mathrm{~kg} \mathrm{~m}^{-3}$, chalky calcite: $710 \pm 22.9 \mathrm{~kg} \mathrm{~m}^{-3}$. Gender names, corresponding to the first word of Latin names, are used throughout the article. 


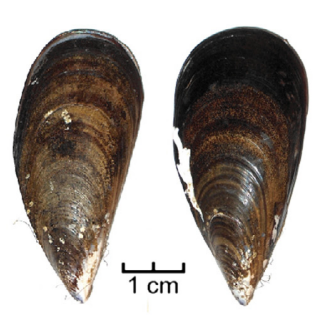

Mytilus edulis (Mussel)

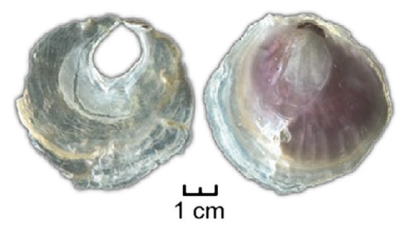

Anomia ephippium (Saddle oyster)
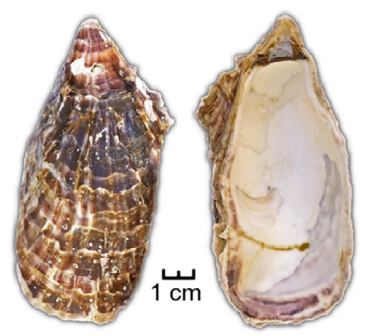

Magallana gigas (Japanese oyster)

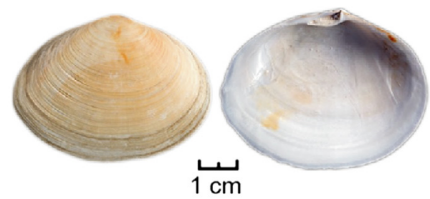

Scrobicularia plana (Peppery furrow shell)

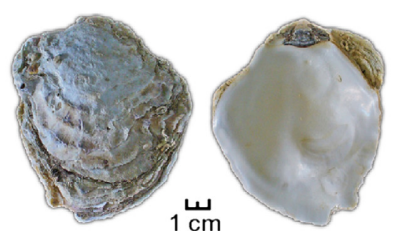

Ostrea edulis (Flat oyster)

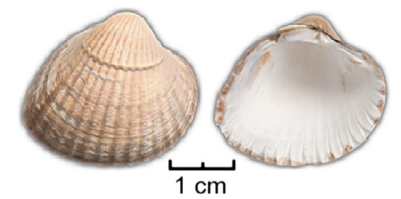

Cerastoderma edule (Cockle)

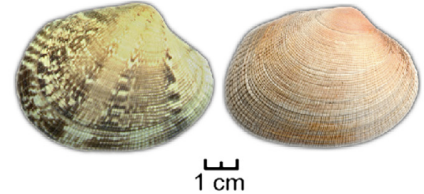

Ruditapes philippinarum (Manila clam)

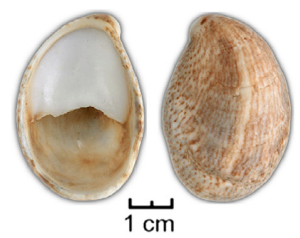

Crepidula fornicata (Slipper limpet)

Fig. 1. Photographs of the eight mollusc species used for the experiments, collected on a shelly beach ridge (Mont-Saint-Michel Bay, France).

$4.0 \mathrm{~mm} ; 4.0$ to $6.30 \mathrm{~mm}$; and more than $6.30 \mathrm{~mm}$. Five individual size fractions were used for threshold experiments, and included: 0.63 to $0.8 \mathrm{~mm} ; 0.8$ to $1.25 \mathrm{~mm} ; 1.25$ to $2 \mathrm{~mm} ; 2$ to $3.15 \mathrm{~mm}$; and 3.15 to $5 \mathrm{~mm}$. Mean diameter corresponding to the average of the sieve bounds is used in calculations. In the following, a sediment sample has been defined as the combination of a given grain-size class and a mollusc species. Hammered particles were observed by the naked eye and under a binocular microscope, and compared with natural shell debris of the same size and species collected in the field (Fig. 2). No significant differences were found in terms of particle shape, except that the edges of artificial debris were sharper than the natural particles. The hammering process was obviously very different from the natural processes of shell fragmentation by abrasion or predation (Driscoll, 1967; Cadée, 1994; Zuschin et al., 2003; Newell et al., 2007; Gorzelak et al., 2013) but it was found to be the most efficient and fast process to obtain sufficient quantities of material. Visual observations were reported on the behaviour of the shells during the fragmentation process (mechanical resistance, delamination, shape and size of debris).

For each sample, the density of dry bioclastic particles was measured five times using a $100 \mathrm{ml}$ pycnometer (from BYK-Gardner GmBH, Geretsried,
Germany) filled with freshwater at $20^{\circ} \mathrm{C}$. Finally, electron micrographs of shell debris were acquired for each species using a Zeiss EVO 40 EP scanning electron microscope (SEM; Carl Zeiss AG, Oberkochen, Germany) focusing on particle edges to observe internal shell structures.

\section{Determination of settling velocities}

Settling velocities $\left(w_{s}\right)$ of individual bioclastic particles were measured in a settling tube for each species and sieve size based on the experimental procedure described in Weill et al. (2010). The tube was $2.0 \mathrm{~m}$ in length and $0.20 \mathrm{~m}$ in width. A Nikon D700 camera with a Speedlight SB-24 flash (Nikon Corporation, Tokyo, Japan) was placed at the middle of the column to take stroboscopic photographs. Debris was deposited by hand on the top of the water column, without an initial velocity. When the studied particle reached its steady state velocity, a photograph was taken by the camera for $2 \mathrm{sec}$ (exposure time) under a $5 \mathrm{~Hz}$ stroboscopic lightning. Settling velocities were determined from analysis of the photograph, which displayed seven successive pictures of the particle, separated by a $0.2 \mathrm{sec}$ time lag. For each size/species combination, $w_{s}$ of 20 to 40 particles were measured. To avoid border effects, only particles 

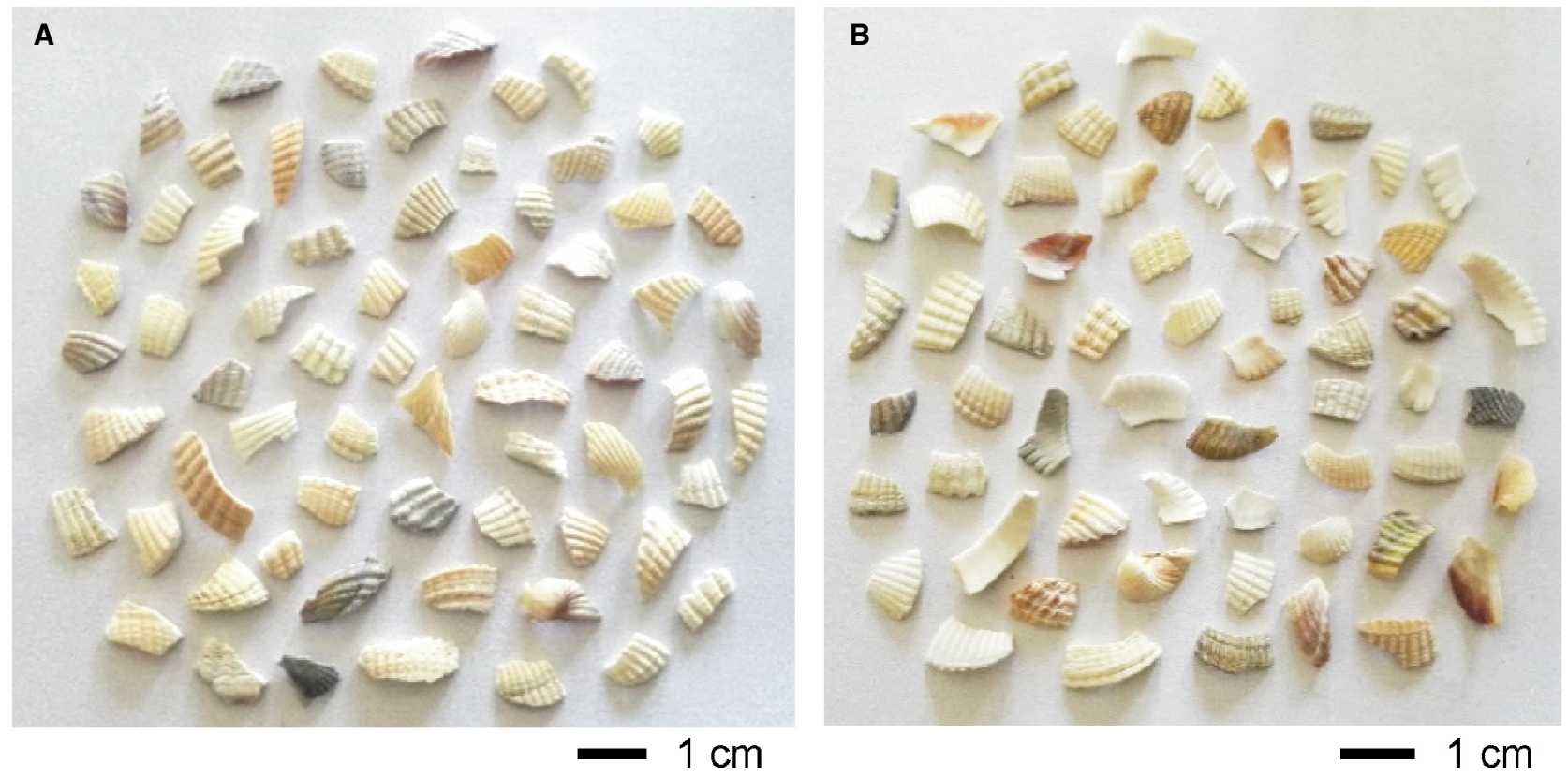

Fig. 2. (A) Photographs of Cerastoderma debris obtained after manual hammering of adult shells, compared with (B) natural debris sampled in the field. Note the similar shapes, suggesting that production of shell debris is unbiased by hammering.

falling in the centre of the tube were taken into account. The global error consists of the addition of two terms, one in space and one in time. The error in space reaches $2 \cdot 5 \%$ and the one in time (stroboscopic flash) is given at $2 \cdot 0 \%$ for the worst cases, which makes a global error of about $4.5 \%$ on $w_{S}$ values.

The equation of Van Rijn (1993) was used to fit data (Eq. 1) and to determine the drag coefficient $\left(C_{D}\right)$ :

$$
W_{s}=\left[\frac{4\left(\rho_{s}-1\right) g D_{\text {sieve }}}{3 C_{D}}\right]^{0.5}
$$

where $\rho_{s}$ is the sediment density, $g$ is the acceleration of gravity and $D_{\text {sieve }}$ is the particle sieve diameter. Settling velocities of glass beads have been measured to check the consistency of the experimental procedure. The drag coefficient obtained $\left(C_{D}=0.45 \pm 0.02\right)$ is in agreement with empirical values.

\section{Determination of threshold of motion}

Flume setup and sediment bed disposal

Threshold experiments were performed in a steady-flow, unidirectional-current flume (Fig. 3) filled with freshwater. The test section consisted of a $2.0 \mathrm{~m}$ long, $0.1 \mathrm{~m}$ wide and $0.25 \mathrm{~m}$ deep glass-sided channel. Water was supplied by a circulation system with a recycling tank and a centrifugal pump with a maximum capacity of $53 \mathrm{~m}^{3} \mathrm{~h}^{-1}$. Turbulence at the inflow was dissipated with alveolar foam and a honeycomb flow straightener, preceding a trumpet-shaped convergent inlet. Flow depth was controlled at the downstream end of the flume with a gate evenly drilled with holes, to ensure a more homogeneous velocity distribution across the water column than there would be with a simple overspill. Gates of different hydraulic head losses were used to change the range of flow velocity. Fine tuning of flow velocity was achieved by adjusting the pump power.

Sediment samples were placed in the empty flume between two wedges to form a $1 \mathrm{~m}$ long and $2 \mathrm{~cm}$ thick sediment bed starting at $0.5 \mathrm{~m}$ from the converging entrance section. The flume was slowly filled with water up to a depth of $8 \mathrm{~cm}$ above the bed. The flow velocity was then progressively increased until the initiation of sediment motion. The velocity ramp was performed within a few minutes to prevent long exposures at pre-threshold velocity, which are likely to increase the bed resistance (Paphitis \& Collins, 2005). Detection of the threshold of motion was performed visually following the Kramer (1935) medium stage definition: "[...] 


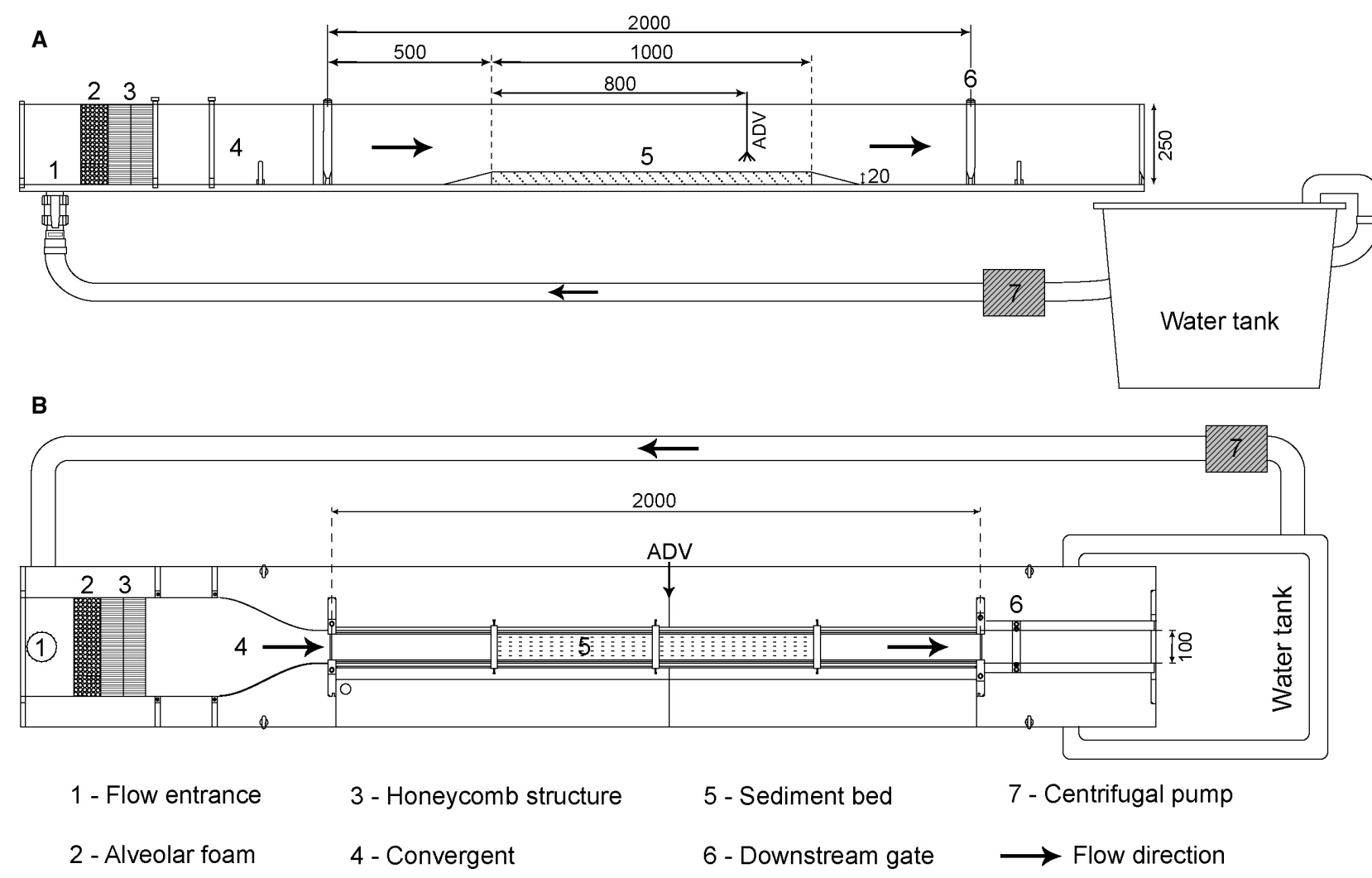

Fig. 3. (A) Cross-section and (B) plan view of the recirculating flume showing the position of the Acoustic Doppler Velocimeter (ADV) Profiler (Vectrino Profiler) relative to the $2 \mathrm{~cm}$ thick sediment bed. All dimensions are in millimetres.

grains of mean diameter are in motion in numbers too large to be countable [...] movement is no longer local in character. It is not strong enough to affect bed configuration.”. Between each experiment, the sediment bed was entirely reworked and smoothed to recover the same initial conditions of a flat and unarmoured bed.

\section{Threshold velocity measurements}

Velocity profiles were acquired at threshold velocity to calculate the critical bed shear stress $\left(\tau_{\text {ocr }}\right)$ of the samples. For each sediment sample (defined by a grain size and a mollusc species combination), between seven and ten replicates were performed making a total of about 300 experiments. A larger number of replicates was performed when a larger dispersion of $\tau_{\text {ocr }}$ between replicates was observed. Two additional tests with fine quartz sand (Fontainebleau sand) sieved between $125 \mu \mathrm{m}$ and $160 \mu \mathrm{m}$ (median diameter $142.5 \mu \mathrm{m}$ ), and glass beads (median diameter $1.025 \mathrm{~mm}$ ), were performed to check the consistency of the results obtained in the flume with empirical prediction curves.
Velocity profiles were collected using an acoustic doppler velocimeter profiler (ADVP; Nortek Vectrino Profiler; Nortek, Vangkroken, Norway), positioned $1.30 \mathrm{~m}$ downstream of the test section entrance and $0.8 \mathrm{~m}$ after the beginning of the sediment bed to ensure a fully developed boundary layer. Velocity profile recording time was set at $120 \mathrm{sec}$, based on mean flow velocity convergence tests. The ADVP records the three components of the flow velocity over a $35 \mathrm{~mm}$ range located between $40 \mathrm{~mm}$ and $75 \mathrm{~mm}$ from the emitter, with a maximum sampling frequency of $100 \mathrm{~Hz}$ and a vertical resolution of $1 \mathrm{~mm}$ (Craig et al., 2011). The manufacturer accuracy of velocity measurements is $\pm 0.5 \%$ of the measured value $\pm 1 \mathrm{~mm} \mathrm{sec}^{-1}$ (NortekAs). It appeared that the signal quality (signal to noise ratio - SNR, beam correlation and amplitude) significantly decreased away from the point of maximum beam correlation located at $50 \mathrm{~mm}$ from the emitter, following a roughly parabolic distribution, due to the probe geometry (decreasing overlap of individual beams). It introduced a bias with underestimated mean velocity values, up to $10 \%$ in the lower 
$10 \mathrm{~mm}$ of the profile (Macvicar et al., 2014; Brand et al., 2016). In a $10 \mathrm{~mm}$ range around the maximum beam correlation point (called the 'sweet spot'), the signal quality was good and constant, and the mean velocity values showed no deviation when compared with other measurement techniques [standard acoustic doppler velocimeter (ADV) - Brand et al., 2016; particle image velocimetry (PIV) - Ruonan et al., 2016]. For this reason, in this study, $25 \mathrm{~mm}$ vertical velocity profiles were obtained in the boundary layer using five stacked profiles of $10 \mathrm{~mm}$ (in the sweet spot), with overlapping regions of about $5 \mathrm{~mm}$ (Fig. 4). Elevation of the velocity profiles above the bed was measured at $1 \mathrm{~Hz}$ by simple echo ranging interleaved with velocity measurement bursts. Velocity measurements close to the sedimentwater interface were biased due to strong bottom echoes interfering with the emitted pulse. The extent of the interference region above the sedimentwater interface depends on the bed material (roughness and porosity) and has been estimated between $3 \mathrm{~mm}$ and $5 \mathrm{~mm}$ (Rusello \& Allard, 2012; Wengrove \& Foster, 2014; Koca et al., 2017). Measurements in this area were not considered in the interpretation. The ADV profiler was configured at its highest sampling rate $(100 \mathrm{~Hz})$ and spatial resolution $(1 \mathrm{~mm})$ to estimate the turbulent properties of the flow. Sampling rate has negligible influence on mean velocity, but affects the estimation of turbulent intensity (Ruonan et al., 2016). The flow was seeded with hollow glass microspheres (SPHERICEL ${ }^{\circledR}$ 110P8; Potters Industries
LLC, Malvern, PA, USA) as recommended by Nortek; the ADVP manufacturer. Microspheres had a median size of $10 \mu \mathrm{m}$ and a true density of $1.10 \mathrm{~g} \mathrm{~cm}^{-3}$. Data were filtered at threshold values of $20 \mathrm{~dB}$ for the SNR and $80 \%$ for the beam correlation.

Velocity measurements acquired at threshold of motion showed hydraulically smooth to rough flows, depending on the grain size/species combination. The turbulent, logarithmic boundary layer was clearly observed, and extended between $1.5 \mathrm{~cm}$ and $2.5 \mathrm{~cm}$ above the bed, depending on the particle size (bed roughness) and flow velocity. Because the first millimetres above the sediment-water interface could not be surveyed with the ADVP (strong bottom acoustic reflection), no velocity measurements were taken in the viscous sub-layer at low Reynolds number. Thus, all bottom shear velocity $\left(u_{*}\right)$ estimations were undertaken using the law of the wall in the logarithmic layer. It is important to note that $\tau_{\text {ocr }}$ derived from the log layer in hydraulically smooth to transitional flows may not be representative of the real velocity gradients at the sediment-water interface. Weill et al. (2010) reported precise velocity measurements in the boundary layer on similar material (bioclastic sand) using laser doppler velocimetry (LDV), including in the viscous sublayer. The results showed that $\tau_{0 \mathrm{cr}}$ calculated from velocity gradient in the viscous sub-layer in hydraulically smooth to transitional flows were around half of the values calculated from the law of the wall in the turbulent logarithmic layer.
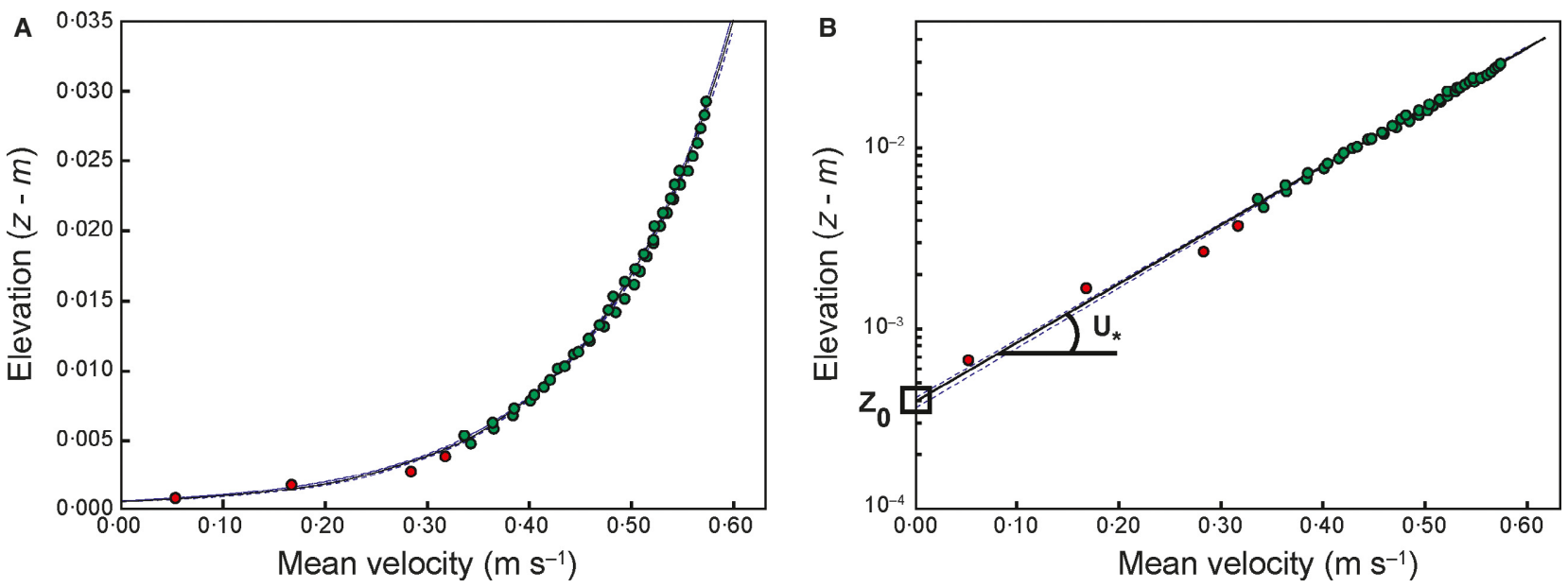

Fig. 4. Example of velocity profile data obtained with the Vectrino Profiler and the regression in the logarithmic layer with confidence intervals at two standard deviations. The profile shows the mean velocity as a function of the elevation above the bed. (A) Linear vertical scale. (B) Logarithmic vertical scale with the determination of the zero level velocity $\left(\mathrm{z}_{0}\right)$ as the intercept of the log layer with the elevation axis, and the critical shear velocity ( $\mathrm{u} *$ ) as the slope of the log layer. Green points represent values used in the regression analysis in the log layer.

(C) 2018 The Authors. Sedimentology (C) 2018 International Association of Sedimentologists, Sedimentology, 66, 895-916 


\section{Critical shear stress calculation}

Critical bed shear stress can be derived from turbulence characteristics in the boundary layer (Reynolds stress and turbulent kinetic energy) or from a time-averaged velocity profile. The estimations of bottom shear stress between these techniques can show important differences of up to $40 \%$ (Biron et al., 2004). In this study, critical bed shear stress values were derived from mean velocity profiles in the boundary layer, by using the law of the wall technique, for two reasons: (i) mean velocity measurements are not sensitive to the sampling frequency of the Vectrino Profiler, and less sensitive to noise and signal decorrelation along the profile, compared to turbulence estimation based on velocity deviation; and (ii) most studies on bioclastic sediment (Paphitis et al., 2002; Weill et al., 2010; Joshi et al., 2017) report bed shear stress derived from law of the wall regression on mean velocity profiles, and the same method should be applied in order to compare the results of this study.

The structure of the boundary layer depends on the hydraulic regime of the flow given by the grain Reynolds number:

$$
\operatorname{Re} *=\frac{u * D_{\text {sieve }}}{v}
$$

where $v$ is the coefficient of kinematic viscosity of water.

Boundary layers in hydraulically smooth flows $\left(\mathrm{Re}^{*} \leq 5\right)$ are composed of a millimetric viscous sub-layer close to the sediment-water interface (linear velocity profile), followed by a centimetric turbulent layer defined by a logarithmic velocity profile. When $5 \leq \operatorname{Re}^{*} \leq 70$, the flow is said to be transitional. The viscous sub-layer is thinner and intermittently dislocated by turbulent bursts, because the roughness height of the bed becomes of the same order of magnitude as the viscous sub-layer height. For hydraulically rough flows ( $\operatorname{Re}^{*} \geq 70$ ), the viscous sub-layer no longer subsists and the turbulent log-layer holds down to the sediment-water interface. The general formulation of the turbulent log-layer, independent of the hydraulic regime of the flow, is referred to as the law of the wall:

$$
u(z)=\frac{u *}{\kappa}\left(\frac{\mathrm{z}}{z_{0}}\right)
$$

where $u(z)$ is the streamwise mean velocity at the elevation $z$ above the bed, $\kappa$ is the von Kármán constant ( $c a$ 0.4) and $z_{0}$ is the distance from the bed at which the velocity predicted by the law of the wall equals zero.

The value of $u *$ is calculated using a linear regression of $u$ on $\ln (z)$ [graphically, $u_{*}$ is the slope of $u \ln (z)$; Fig. 4]: $z_{0}$, defined as the nullvelocity elevation, corresponds to the intercept of the log-layer with the z-axis (Fig. 4). Confidence intervals of the slope and intercept (two standard deviations) were computed to derive the statistical errors of the $u^{*}$ and $z_{0}$ parameters (Wilkinson, 1983; Joshi et al., 2017). Critical bed shear stress is derived from $u_{*}$ :

$$
\tau_{0 \mathrm{cr}}=\rho u_{*}^{2}
$$

where $\rho$ is the mass density of water.

Bottom roughness influences the velocity distribution above the bed because eddies are generated by the particles protruding above the mean bed level. Nikuradse (1933) showed that the length $z_{0}$ is related to the roughness of the bed surface, and introduced the concept of equivalent grain roughness $\left(k_{s}\right)$, also called the Nikuradse equivalent roughness length. For hydraulically rough flows (Van Rijn, 1993):

$$
k_{s}=30 z_{0}
$$

For hydraulically transitional flows (Van Rijn, 1993):

$$
k_{s}=30\left[z_{0}-0 \cdot 11 \frac{v}{u_{*}}\right]
$$

$k_{s}$ is an important parameter used in sediment transport models, and values obtained from a mono-specific shell debris bed are reported in this study (Table 2).

In order to compare the entrainment threshold of bioclastic particles to sediments of different densities or shapes, $\tau_{\text {ocr }}$ (or $u_{*}$ ) can be expressed in terms of non-dimensional parameters, such as the Shields entrainment function $(\theta)$ and the movability number $(\mathrm{Mn})$. $\theta$ shows the ratio of the fluid force acting on a particle to the immersed weight of the particle:

$$
\theta=\frac{\tau_{0 \mathrm{cr}}}{\left(\rho_{\mathrm{s}}-\rho\right) g D_{\text {sieve }}}
$$

However, this parameter does not take into account the shape of the particle, which has a direct influence on the flow drag around the grain, and thus on the grain resistance to the flow. The movability number (Mn; Liu, 1957; 
Table 2. Experimental parameters at the entrainment threshold.

\begin{tabular}{|c|c|c|c|c|c|c|c|c|}
\hline Species & $\begin{array}{l}\text { Sieve } \\
\text { diameter } \\
(\mathrm{mm}) \\
D_{\text {sieve }}\end{array}$ & $\begin{array}{l}\text { Critical } \\
\text { shear } \\
\text { velocity } \\
\left(\mathrm{m} \mathrm{s}^{-1}\right) \\
u^{*}\end{array}$ & $\begin{array}{l}\text { Grain } \\
\text { Reynolds } \\
\text { number } \\
\text { Re* }^{*}\end{array}$ & $\begin{array}{l}\text { Equivalent } \\
\text { roughness } \\
\text { length }(\mathrm{m}) \\
k_{s}\end{array}$ & $\begin{array}{l}\text { Mean } \\
\text { critical } \\
\text { shear stress } \\
\left(\mathrm{N} \mathrm{m}^{-2}\right) \\
\tau_{0}\end{array}$ & $\begin{array}{l}\text { Settling } \\
\text { velocity } \\
\left(\mathrm{m} \mathrm{s}^{-1}\right) \\
W_{s}\end{array}$ & $\begin{array}{l}\text { Shields } \\
\text { entrainment } \\
\text { function } \\
\theta\end{array}$ & $\begin{array}{l}\text { Movability } \\
\text { number } \\
\text { Mn }\end{array}$ \\
\hline & $\begin{array}{l}0 \cdot 715 \\
1 \cdot 025 \\
1 \cdot 625 \\
2 \cdot 575 \\
4 \cdot 075\end{array}$ & $\begin{array}{l}1.31 \times 10^{-2} \\
1.80 \times 10^{-2} \\
2.71 \times 10^{-2} \\
3.68 \times 10^{-2} \\
4.41 \times 10^{-2}\end{array}$ & $\begin{array}{r}9 \cdot 3 \\
18 \cdot 5 \\
44 \cdot 1 \\
94 \cdot 8 \\
179 \cdot 8\end{array}$ & $\begin{array}{l}- \\
6 \cdot 86 \times 10^{-4} \\
1.47 \times 10^{-3} \\
4.08 \times 10^{-3} \\
5 \cdot 82 \times 10^{-3}\end{array}$ & $\begin{array}{l}1.74 \times 10^{-1} \\
3.25 \times 10^{-1} \\
7.45 \times 10^{-1} \\
1.42 \\
1.99\end{array}$ & $\begin{array}{l}8.43 \times 10^{-2} \\
9.41 \times 10^{-2} \\
1.08 \times 10^{-1} \\
1.25 \times 10^{-1} \\
1.43 \times 10^{-1}\end{array}$ & $\begin{array}{l}1.38 \times 10^{-2} \\
1 \cdot 79 \times 10^{-2} \\
2 \cdot 59 \times 10^{-2} \\
3 \cdot 13 \times 10^{-2} \\
2 \cdot 76 \times 10^{-2}\end{array}$ & $\begin{array}{l}1.55 \times 10^{-1} \\
1.92 \times 10^{-1} \\
2.50 \times 10^{-1} \\
2.95 \times 10^{-1} \\
3.08 \times 10^{-1}\end{array}$ \\
\hline Scrobicularia & $\begin{array}{l}0 \cdot 715 \\
1 \cdot 025 \\
1 \cdot 625 \\
2 \cdot 575 \\
4 \cdot 075\end{array}$ & $\begin{array}{l}1.42 \times 10^{-2} \\
1.82 \times 10^{-2} \\
2.83 \times 10^{-2} \\
3.75 \times 10^{-2} \\
4.36 \times 10^{-2}\end{array}$ & $\begin{array}{r}10 \cdot 1 \\
18 \cdot 6 \\
46 \cdot 0 \\
96 \cdot 7 \\
177 \cdot 6\end{array}$ & $\begin{array}{l}- \\
4.93 \times 10^{-4} \\
1.49 \times 10^{-3} \\
3.46 \times 10^{-3} \\
8.22 \times 10^{-3}\end{array}$ & $\begin{array}{l}2.05 \times 10^{-1} \\
3.33 \times 10^{-1} \\
8.08 \times 10^{-1} \\
1.45 \\
1.99\end{array}$ & $\begin{array}{l}8.35 \times 10^{-2} \\
8 \cdot 74 \times 10^{-2} \\
9 \cdot 26 \times 10^{-2} \\
9 \cdot 81 \times 10^{-2} \\
1.04 \times 10^{-1}\end{array}$ & $\begin{array}{l}1.64 \times 10^{-2} \\
1 \cdot 86 \times 10^{-2} \\
2 \cdot 84 \times 10^{-2} \\
3 \cdot 22 \times 10^{-2} \\
2 \cdot 79 \times 10^{-2}\end{array}$ & $\begin{array}{l}1 \cdot 70 \times 10^{-1} \\
2 \cdot 08 \times 10^{-1} \\
3 \cdot 06 \times 10^{-1} \\
3 \cdot 82 \times 10^{-1} \\
4 \cdot 19 \times 10^{-1}\end{array}$ \\
\hline Cerastod & $\begin{array}{l}0 \cdot 715 \\
1 \cdot 025 \\
1 \cdot 625 \\
2 \cdot 575 \\
4 \cdot 075\end{array}$ & $\begin{array}{l}1.46 \times 10^{-2} \\
2.03 \times 10^{-2} \\
2.95 \times 10^{-2} \\
4.37 \times 10^{-2} \\
4.99 \times 10^{-2}\end{array}$ & $\begin{array}{r}10 \cdot 4 \\
20 \cdot 8 \\
47 \cdot 9 \\
112 \cdot 4 \\
203 \cdot 2\end{array}$ & $\begin{array}{l}4.83 \times 10^{-4} \\
2.61 \times 10^{-4} \\
1.74 \times 10^{-3} \\
3.03 \times 10^{-3} \\
1.12 \times 10^{-2}\end{array}$ & $\begin{array}{l}2 \cdot 14 \times 10^{-1} \\
4.14 \times 10^{-1} \\
8.77 \times 10^{-1} \\
1.98 \\
2.64\end{array}$ & $\begin{array}{l}8 \cdot 74 \times 10^{-2} \\
9 \cdot 31 \times 10^{-2} \\
1 \cdot 01 \times 10^{-1} \\
1 \cdot 10 \times 10^{-1} \\
1 \cdot 19 \times 10^{-1}\end{array}$ & $\begin{array}{l}1 \cdot 72 \times 10^{-2} \\
2 \cdot 32 \times 10^{-2} \\
3 \cdot 10 \times 10^{-2} \\
4.41 \times 10^{-2} \\
3 \cdot 73 \times 10^{-2}\end{array}$ & $\begin{array}{l}1 \cdot 67 \times 10^{-1} \\
2 \cdot 18 \times 10^{-1} \\
2 \cdot 92 \times 10^{-1} \\
3.98 \times 10^{-1} \\
4 \cdot 19 \times 10^{-1}\end{array}$ \\
\hline apes & $\begin{array}{l}0 \cdot 715 \\
1 \cdot 025 \\
1 \cdot 625 \\
2 \cdot 575 \\
4 \cdot 075\end{array}$ & $\begin{array}{l}1.20 \times 10^{-2} \\
1.83 \times 10^{-2} \\
2.97 \times 10^{-2} \\
4.45 \times 10^{-2} \\
5.04 \times 10^{-2}\end{array}$ & $\begin{array}{r}8 \cdot 6 \\
18 \cdot 8 \\
48 \cdot 3 \\
114 \cdot 5 \\
205 \cdot 5\end{array}$ & $\begin{array}{l}- \\
6 \cdot 69 \times 10^{-4} \\
9 \cdot 58 \times 10^{-4} \\
3 \cdot 42 \times 10^{-3} \\
8 \cdot 78 \times 10^{-3}\end{array}$ & $\begin{array}{l}1.47 \times 10^{-1} \\
3 \cdot 37 \times 10^{-1} \\
9 \cdot 05 \times 10^{-1} \\
2 \cdot 02 \\
2 \cdot 60\end{array}$ & $\begin{array}{l}9.06 \times 10^{-2} \\
1.00 \times 10^{-1} \\
1 \cdot 14 \times 10^{-1} \\
1.30 \times 10^{-1} \\
1.48 \times 10^{-1}\end{array}$ & $\begin{array}{l}1.20 \times 10^{-2} \\
1.91 \times 10^{-2} \\
3 \cdot 24 \times 10^{-2} \\
4.56 \times 10^{-2} \\
3 \cdot 70 \times 10^{-2}\end{array}$ & $\begin{array}{l}1.33 \times 10^{-1} \\
1.83 \times 10^{-1} \\
2 \cdot 60 \times 10^{-1} \\
3.42 \times 10^{-1} \\
3.41 \times 10^{-1}\end{array}$ \\
\hline Myt & $\begin{array}{l}0 \cdot 715 \\
1 \cdot 025 \\
1 \cdot 625 \\
2 \cdot 575 \\
4 \cdot 075\end{array}$ & $\begin{array}{l}1 \cdot 25 \times 10^{-2} \\
1.29 \times 10^{-2} \\
2 \cdot 24 \times 10^{-2} \\
3 \cdot 50 \times 10^{-2} \\
5 \cdot 00 \times 10^{-2}\end{array}$ & $\begin{array}{r}9 \cdot 0 \\
13 \cdot 3 \\
36 \cdot 3 \\
90 \cdot 2 \\
203 \cdot 8\end{array}$ & $\begin{array}{l}4.75 \times 10^{-4} \\
- \\
6.98 \times 10^{-4} \\
3.39 \times 10^{-3} \\
6.56 \times 10^{-3}\end{array}$ & $\begin{array}{l}1.59 \times 10^{-1} \\
1.69 \times 10^{-1} \\
5.06 \times 10^{-1} \\
1.25 \\
2.54\end{array}$ & $\begin{array}{l}5 \cdot 98 \times 10^{-2} \\
6 \cdot 52 \times 10^{-2} \\
7 \cdot 29 \times 10^{-2} \\
8 \cdot 14 \times 10^{-2} \\
9 \cdot 09 \times 10^{-2}\end{array}$ & $\begin{array}{l}1 \cdot 36 \times 10^{-2} \\
1 \cdot 01 \times 10^{-2} \\
1 \cdot 91 \times 10^{-2} \\
2 \cdot 97 \times 10^{-2} \\
3 \cdot 82 \times 10^{-2}\end{array}$ & $\begin{array}{l}2 \cdot 10 \times 10^{-1} \\
1.98 \times 10^{-1} \\
3.07 \times 10^{-1} \\
4.30 \times 10^{-1} \\
5.50 \times 10^{-1}\end{array}$ \\
\hline Anc & $\begin{array}{l}0 \cdot 715 \\
1 \cdot 025 \\
1 \cdot 625 \\
2 \cdot 575 \\
4 \cdot 075\end{array}$ & $\begin{array}{l}7 \cdot 19 \times 10^{-3} \\
1.18 \times 10^{-2} \\
1.48 \times 10^{-2} \\
1.95 \times 10^{-2} \\
3.25 \times 10^{-2}\end{array}$ & $\begin{array}{r}5 \cdot 1 \\
12 \cdot 1 \\
24 \cdot 0 \\
50 \cdot 2 \\
133 \cdot 4\end{array}$ & $\begin{array}{l}- \\
1.63 \times 10^{-3} \\
1.62 \times 10^{-3} \\
2.82 \times 10^{-3} \\
8.62 \times 10^{-3}\end{array}$ & $\begin{array}{l}5.36 \times 10^{-2} \\
1.40 \times 10^{-1} \\
2 \cdot 22 \times 10^{-1} \\
3.82 \times 10^{-1} \\
1.06\end{array}$ & $\begin{array}{l}2 \cdot 33 \times 10^{-2} \\
2 \cdot 77 \times 10^{-2} \\
3 \cdot 47 \times 10^{-2} \\
4.34 \times 10^{-2} \\
5 \cdot 43 \times 10^{-2}\end{array}$ & $\begin{array}{l}4.68 \times 10^{-3} \\
8.56 \times 10^{-3} \\
8.55 \times 10^{-3} \\
9 \cdot 27 \times 10^{-3} \\
1.62 \times 10^{-2}\end{array}$ & $\begin{array}{l}3.09 \times 10^{-1} \\
4.26 \times 10^{-1} \\
4.26 \times 10^{-1} \\
4.48 \times 10^{-1} \\
5.98 \times 10^{-1}\end{array}$ \\
\hline $\begin{array}{l}\text { na } \\
\text { old 1) }\end{array}$ & $\begin{array}{l}0 \cdot 715 \\
1 \cdot 025 \\
1 \cdot 625 \\
2 \cdot 575 \\
4 \cdot 075\end{array}$ & $\begin{array}{l}6 \cdot 43 \times 10^{-3} \\
8 \cdot 11 \times 10^{-3} \\
1.50 \times 10^{-2} \\
2 \cdot 38 \times 10^{-2} \\
3.45 \times 10^{-2}\end{array}$ & $\begin{array}{r}4 \cdot 6 \\
8 \cdot 3 \\
24 \cdot 5 \\
61 \cdot 2 \\
140 \cdot 5\end{array}$ & $\begin{array}{l}- \\
- \\
9.56 \times 10^{-4} \\
3 \cdot 02 \times 10^{-3} \\
4.81 \times 10^{-3}\end{array}$ & $\begin{array}{l}4.29 \times 10^{-2} \\
6 \cdot 72 \times 10^{-2} \\
2 \cdot 28 \times 10^{-1} \\
5 \cdot 67 \times 10^{-1} \\
1.20\end{array}$ & $\begin{array}{l}3.84 \times 10^{-2} \\
4.48 \times 10^{-2} \\
5.45 \times 10^{-2} \\
6.63 \times 10^{-2} \\
8.06 \times 10^{-2}\end{array}$ & $\begin{array}{l}5 \cdot 65 \times 10^{-3} \\
6 \cdot 17 \times 10^{-3} \\
1 \cdot 32 \times 10^{-2} \\
2 \cdot 07 \times 10^{-2} \\
2 \cdot 78 \times 10^{-2}\end{array}$ & $\begin{array}{l}1.67 \times 10^{-1} \\
1.81 \times 10^{-1} \\
2.76 \times 10^{-1} \\
3.59 \times 10^{-1} \\
4.28 \times 10^{-1}\end{array}$ \\
\hline $\begin{array}{l}\text { Magallana } \\
\text { (threshold 2) }\end{array}$ & $\begin{array}{l}0 \cdot 715 \\
1 \cdot 025 \\
1 \cdot 625 \\
2 \cdot 575 \\
4 \cdot 075\end{array}$ & $\begin{array}{l}1.45 \times 10^{-2} \\
1.68 \times 10^{-2} \\
2.62 \times 10^{-2} \\
3.32 \times 10^{-2} \\
4.91 \times 10^{-2}\end{array}$ & $\begin{array}{r}10 \cdot 4 \\
17 \cdot 2 \\
42 \cdot 5 \\
85 \cdot 4 \\
199 \cdot 9\end{array}$ & $\begin{array}{l}5 \cdot 80 \times 10^{-4} \\
9 \cdot 77 \times 10^{-4} \\
1.88 \times 10^{-3} \\
5 \cdot 05 \times 10^{-3} \\
1.28 \times 10^{-2}\end{array}$ & $\begin{array}{l}2 \cdot 13 \times 10^{-1} \\
2 \cdot 84 \times 10^{-1} \\
6 \cdot 86 \times 10^{-1} \\
1 \cdot 11 \\
2 \cdot 47\end{array}$ & $\begin{array}{l}3.84 \times 10^{-2} \\
4.48 \times 10^{-2} \\
5.45 \times 10^{-2} \\
6 \cdot 63 \times 10^{-2} \\
8.06 \times 10^{-2}\end{array}$ & $\begin{array}{l}2.05 \times 10^{-2} \\
1.91 \times 10^{-2} \\
2.91 \times 10^{-2} \\
2.96 \times 10^{-2} \\
4.18 \times 10^{-2}\end{array}$ & $\begin{array}{l}3 \cdot 78 \times 10^{-1} \\
3 \cdot 76 \times 10^{-1} \\
4 \cdot 81 \times 10^{-1} \\
5 \cdot 00 \times 10^{-1} \\
6.09 \times 10^{-1}\end{array}$ \\
\hline $\begin{array}{l}\text { Ostrea } \\
\text { (threshold 1) }\end{array}$ & $\begin{array}{l}0 \cdot 715 \\
1 \cdot 025 \\
1 \cdot 625 \\
2 \cdot 575 \\
4 \cdot 075\end{array}$ & $\begin{array}{l}5 \cdot 11 \times 10^{-3} \\
8.52 \times 10^{-3} \\
1.27 \times 10^{-2} \\
2 \cdot 33 \times 10^{-2} \\
3.68 \times 10^{-2}\end{array}$ & $\begin{array}{r}3 \cdot 6 \\
8 \cdot 7 \\
20 \cdot 6 \\
59 \cdot 9 \\
149 \cdot 9\end{array}$ & $\begin{array}{l}- \\
6 \cdot 29 \times 10^{-4} \\
2 \cdot 37 \times 10^{-3} \\
6 \cdot 28 \times 10^{-3} \\
1.01 \times 10^{-2}\end{array}$ & $\begin{array}{l}2 \cdot 74 \times 10^{-2} \\
7 \cdot 31 \times 10^{-2} \\
1.68 \times 10^{-1} \\
5 \cdot 45 \times 10^{-1} \\
1 \cdot 37\end{array}$ & $\begin{array}{l}4.39 \times 10^{-2} \\
4.94 \times 10^{-2} \\
5 \cdot 74 \times 10^{-2} \\
6 \cdot 66 \times 10^{-2} \\
7 \cdot 73 \times 10^{-2}\end{array}$ & $\begin{array}{l}3 \cdot 85 \times 10^{-3} \\
7 \cdot 16 \times 10^{-3} \\
1 \cdot 04 \times 10^{-2} \\
2 \cdot 13 \times 10^{-2} \\
3 \cdot 38 \times 10^{-2}\end{array}$ & $\begin{array}{l}1 \cdot 16 \times 10^{-1} \\
1.73 \times 10^{-1} \\
2 \cdot 21 \times 10^{-1} \\
3.49 \times 10^{-1} \\
4.75 \times 10^{-1}\end{array}$ \\
\hline $\begin{array}{l}\text { Ostrea } \\
\text { (threshold 2) }\end{array}$ & $\begin{array}{l}0 \cdot 715 \\
1 \cdot 025 \\
1 \cdot 625 \\
2 \cdot 575 \\
4 \cdot 075\end{array}$ & $\begin{array}{l}1.19 \times 10^{-2} \\
1.55 \times 10^{-2} \\
2.58 \times 10^{-2} \\
3.28 \times 10^{-2} \\
4.76 \times 10^{-2}\end{array}$ & $\begin{array}{r}8 \cdot 5 \\
15 \cdot 9 \\
41 \cdot 9 \\
84 \cdot 5 \\
194 \cdot 0\end{array}$ & $\begin{array}{l}- \\
6 \cdot 10 \times 10^{-4} \\
4.06 \times 10^{-3} \\
4.33 \times 10^{-3} \\
1.27 \times 10^{-2}\end{array}$ & $\begin{array}{l}1.44 \times 10^{-1} \\
2.43 \times 10^{-1} \\
6.74 \times 10^{-1} \\
1.08 \\
2.34\end{array}$ & $\begin{array}{l}4.39 \times 10^{-2} \\
4.94 \times 10^{-2} \\
5 \cdot 74 \times 10^{-2} \\
6 \cdot 66 \times 10^{-2} \\
7 \cdot 73 \times 10^{-2}\end{array}$ & $\begin{array}{l}1.38 \times 10^{-2} \\
1.63 \times 10^{-2} \\
2 \cdot 86 \times 10^{-2} \\
2 \cdot 88 \times 10^{-2} \\
3.96 \times 10^{-2}\end{array}$ & $\begin{array}{l}2 \cdot 72 \times 10^{-1} \\
3 \cdot 15 \times 10^{-1} \\
4.49 \times 10^{-1} \\
4.93 \times 10^{-1} \\
6 \cdot 16 \times 10^{-1}\end{array}$ \\
\hline
\end{tabular}


Komar \& Clemens, 1986; Armitage \& Rooseboom, 2010) accounts for the effects of diameter, density and shape factor with the simple parameter of $w_{s}$.

$$
\mathrm{Mn}=\frac{u_{*}}{W_{S}}
$$

\section{RESULTS}

\section{Particle characteristics}

Shells of the eight studied molluscs strongly differ in terms of shape (Fig. 1) and internal structure, as observed during the breakage process, by density measurements (Table 1) or by inspection of the scanning electron photomicrographs (Fig. 5). Crepidula, Cerastoderma and Ruditapes shells are moderately to highly curved, thick and showed a high resistance to breakage; their density is high, above $2750 \mathrm{~kg} \mathrm{~m}^{-3}$ and the shell structure appears homogeneous in SEM images. Scrobicularia shells show a homogeneous structure and a high density $\left(2781 \mathrm{~kg} \mathrm{~m}^{-3}\right)$ as well, but are platy, thin and subsequently more fragile. Mytilus have thin and curved shells of medium density ( $c a 2000 \mathrm{~kg} \mathrm{~m}^{-3}$ ), Anomia have rather thin and platy shells with a density of $2629 \mathrm{~kg} \mathrm{~m}^{-3}$. Shell structure consists of extremely thin foliated layers which, after hammering, produce thin and light flakey debris. Oyster shells can be flat (Ostrea) or highly curved (Magallana), with thicknesses ranging from one to several millimetres. They have an average density of about $2000 \mathrm{~kg} \mathrm{~m}^{-3}$ and display a characteristic structure made of foliated nacreous sheets interstratified with thicker layers of an apparently amorphous soft white mass, chalky in appearance and consistency. Attempts were made to measure the distinct specific gravity values of the two materials of the oyster shell, but density measurements of the chalky deposits were complex. Indeed, the oven-dried chalky mass showed a specific gravity lower than $1\left(710 \mathrm{~kg} \mathrm{~m}^{-3}\right)$, while wet material was denser, with specific gravity increasing with increasing immersion time. This observation suggests that the chalky mass has a high porosity that results in saturation of the material when it is slowly immersed in water. Consequently, it was decided to immerse the oyster fragments in water for two weeks before measuring the specific gravity. A value of $1105 \mathrm{~kg} \mathrm{~m}^{-3}$ was obtained. However, there is no certainty that the time of immersion was sufficient to fully saturate the chalky deposit, nor that this material is saturated with water in nature. The global specific gravity of the foliated nacreous sheets was obtained with a value of $2478 \mathrm{~kg} \mathrm{~m}^{-3}$, but it may be higher because some chalky mass may remain in between sheets of calcite.

\section{Settling velocities}

Settling velocities values are listed in Table 2 and plotted as a function of $D_{\text {sieve }}$ in Fig. 6. Settling velocity values for biogenic particles are clearly lower than reference spherical glass beads, and the difference increases with increasing $D_{\text {sieve. }}$ Significant differences are observed between species, particularly for large grain sizes (Fig. 6). Anomia have the lowest $w_{s}$ with a mean value of $0.066 \mathrm{~m} \mathrm{~s}^{-1}$ for the $6.3 \mathrm{~mm}$ size fraction, while for the same size range Ruditapes and Crepidula have the highest $w_{\mathrm{s}}$ with mean values of $0.20 \mathrm{~m} \mathrm{~s}^{-1}$, i.e. they settle about three times faster than Anomia. Within these lower and upper bounds, Cerastoderma, Scrobicularia, Mytilus, Ostrea and Magallana have intermediate velocities $\left(0.114\right.$ to $\left.0.125 \mathrm{~m} \mathrm{~s}^{-1}\right)$. During the fall, particles displayed different trajectories, from vertical to strongly oscillating, depending on the shape, angularity and surface roughness of the grain (Maiklem, 1968). The fall trajectory influences directly the mean $\mathrm{w}_{\mathrm{s}}$ measured, but the number of replicates for the same sample tends to smooth differences in settling path between particles: $C_{D}$ obtained from $\mathrm{w}_{\mathrm{s}}$ varies depending on the species (Table 3). Anomia have the largest coefficient, of about 30, while Ruditapes and Crepidula have the lowest with values of $3 \cdot 5$ and $4 \cdot 0$, respectively.

\section{Threshold of motion}

Critical bed shear stress values computed from Eq. 4 are listed in Table 2 and plotted in Fig. 7 for all species as a function of $D_{\text {sieve. }}$. For each species, $\tau_{0 \text { cr }}$ increases with $D_{\text {sieve. }}$. Mean values as well as standard deviations calculated from the seven to ten replicates are reported. For comparison, a box (light blue) is also drawn with the lowest and highest values of the standard deviation envelopes of all species. Within each species class, $\tau_{0 \text { cr }}$ and the disparity (standard deviation) of $\tau_{\text {0cr }}$ calculated from the replicates increases with $D_{\text {sieve. }}$. This effect might be attributed to several factors: (i) the progression of the sieve sizes is logarithmic in scale, larger sieve fractions contain 


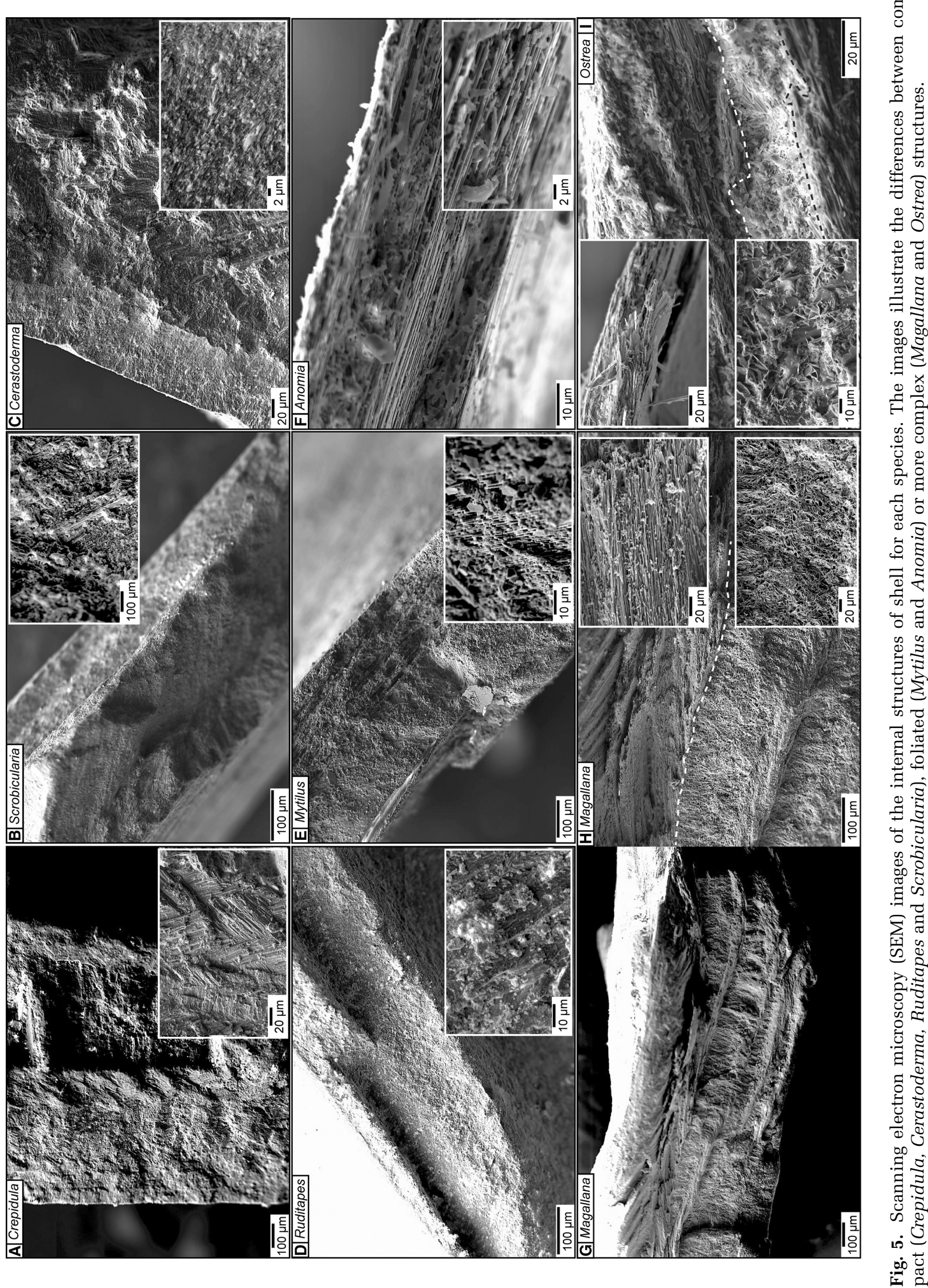

(C) 2018 The Authors. Sedimentology (C) 2018 International Association of Sedimentologists, Sedimentology, 66, 895-916 

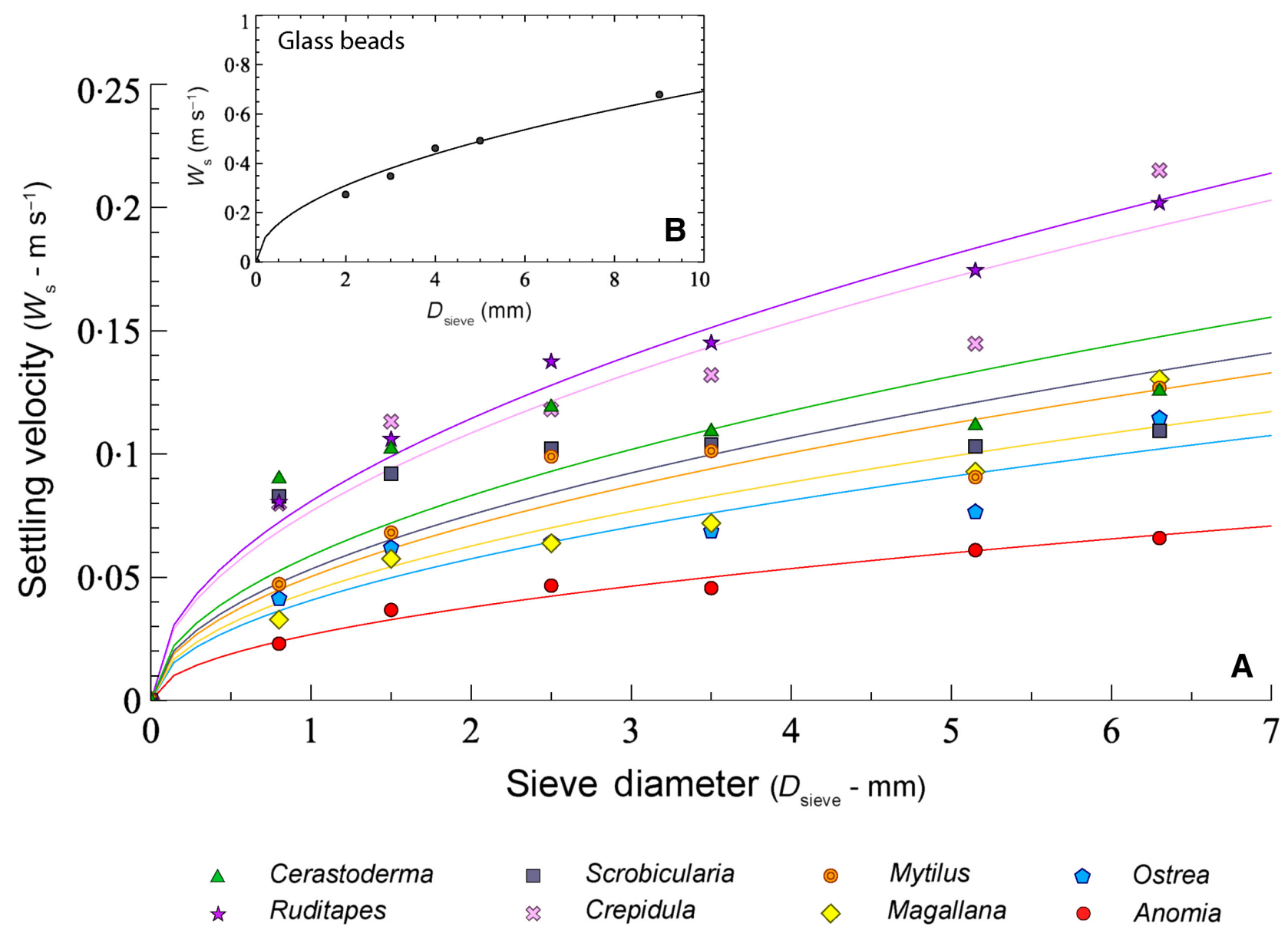

Fig. 6. (A) Settling velocity as a function of sieve diameter for each species. Coloured symbols correspond to the mean settling velocity measured in the settling tube. Coloured lines represent regression curves calculated using the Eq. 1. (B) Settling velocity as a function of sieve diameter for spherical glass beads.

a larger range of particle sizes; (ii) despite all care being taken during the preparation of the shell bed between replicates, some differences in particle arrangement, bed packing and roughness were observed; (iii) turbulence intensity in the flume increases with increasing discharge rates used to mobilize larger particles; turbulent bursts occurring randomly at variable flow velocities are likely to destabilize the bed and initiate motion; and (iv) the importance of the shape factor of the particles increases with increasing $D_{\text {sieve }}$; flat particles can exhibit high resistance to the flow, but the bed can be quickly set in motion with saltation once a few particles are destabilized and offer their large projected surface to the flow.

Significant differences in threshold of motion are observed between species, which are exacerbated with increasing $D_{\text {sieve. Ruditapes and }}$ Cerastoderma show the highest $\tau_{\text {0cr }}$ with mean values of $\mathrm{ca} 2 \cdot 6 \mathrm{~N} \mathrm{~m}^{-2}$ for the 3.15 to $5.0 \mathrm{~mm}$ size fraction. Anomia is the easiest species to mobilize with a mean $\tau_{0 \mathrm{or}}$ of $1 \mathrm{~N} \mathrm{~m}^{-2}$ for the 3.15 to $5.0 \mathrm{~mm}$ size fraction. For the same size fraction, Crepidula and Scrobicularia have intermediate $\tau_{\text {0cr }}$ with a mean value of $c a$ $2 \mathrm{~N} \mathrm{~m}^{-2}$. The unique structure of oysters (Ostrea and Magallana), made of foliated sheets interstratified with amorphous chalky layers, led to the definition of two different thresholds of motion in this study. With a very low density, blocks of amorphous deposits were the first particles to be set in motion (threshold 1). Some particles rolled over the bed, while others were directly put into suspension, or even floated to the surface once detached from the bed. Foliated sheets showed a higher resistance to the flow (threshold 2). Differences in $\tau_{\text {Ocr }}$ between amorphous and foliated layers derived from oyster shells can be in the order of a factor two. For the 2.0 to $3.15 \mathrm{~mm}$ sieve fraction, $\tau_{0 \mathrm{cr}}$ ranges from $0.54 \mathrm{~N} \mathrm{~m}^{-2}$ for the 
Table 3. Drag coefficient by species and coefficients a and $\mathrm{b}$ from Eq. 9 using regression on curves from Fig. 10.

\begin{tabular}{|c|c|c|c|}
\hline Species & $\begin{array}{l}\text { Drag } \\
\text { coefficient } \\
C_{D}\end{array}$ & $\begin{array}{l}\text { Slope } \\
\text { coefficient } \\
a\end{array}$ & $\begin{array}{l}\text { Power } \\
\text { coefficient } \\
b\end{array}$ \\
\hline Crepidula & $4.02 \pm 0.43$ & $2 \cdot 2 \times 10^{4}$ & $4 \cdot 7$ \\
\hline Scrobicularia & $8 \cdot 22 \pm 1 \cdot 61$ & $10^{11}$ & $10 \cdot 8$ \\
\hline Cerastoderma & $6 \cdot 65 \pm 1 \cdot 30$ & $2 \times 10^{8}$ & $8 \cdot 4$ \\
\hline Ruditapes & $3 \cdot 54 \pm 0 \cdot 15$ & $3.5 \times 10^{5}$ & $6 \cdot 0$ \\
\hline Mytilus & $8 \cdot 56 \pm 1 \cdot 01$ & $7 \times 10^{7}$ & $7 \cdot 1$ \\
\hline Anomia & $29 \cdot 8 \pm 1 \cdot 54$ & $1 \cdot 3 \times 10^{4}$ & $3 \cdot 2$ \\
\hline $\begin{array}{l}\text { Magallana } \\
\text { (threshold 2) }\end{array}$ & $7 \cdot 24 \pm 0 \cdot 77$ & $1.8 \times 10^{5}$ & $4 \cdot 7$ \\
\hline $\begin{array}{l}\text { Magallana } \\
\text { (threshold 1) }\end{array}$ & - & $2.5 \times 10^{4}$ & $3 \cdot 7$ \\
\hline $\begin{array}{l}\text { Ostrea } \\
\text { (threshold 2) }\end{array}$ & $8 \cdot 01 \pm 0.91$ & $6 \times 10^{7}$ & $6 \cdot 9$ \\
\hline $\begin{array}{l}\text { Ostrea } \\
\text { (threshold 1) }\end{array}$ & - & $7 \cdot 7 \times 10^{5}$ & $4 \cdot 9$ \\
\hline
\end{tabular}

chalky material to $1.08 \mathrm{~N} \mathrm{~m}^{-2}$ for the foliated sheets.

Mean values of $\tau_{0 \text { cr }}$ obtained for the eight species for different $D_{\text {sieve }}$ are listed in Table 2 and plotted in Fig. 8. The data are compared to the empirical curve and envelope derived by Paphitis (2001) from a compilation of experiments on quartz sand. Values obtained in this study for a quartz sand sample (Fontainebleau sand; median diameter: $142.5 \mu \mathrm{m}$ ), and glass beads (median diameter: $1.025 \mathrm{~mm}$ ) are indicated as well; they are located on the lower limit of the envelope, validating the experimental setup and measurements.

Critical bed shear stress for Cerastoderma, Ruditapes and Scrobicularia fall within the empirical envelope for quartz sand for $D_{\text {sieve }}$ larger than $1 \mathrm{~mm}$. For $D_{\text {sieve }}$ smaller than $1 \mathrm{~mm}$, values are on the lower boundary of the envelope, or slightly lower. In detail, debris derived from Cerastoderma and Ruditapes shells has a slightly higher resistance to the flow, compared to Scrobicularia. Critical bed shear stress values for Anomia fragments are always below the envelope, the difference increasing with decreasing $D_{\text {sieve }}$. The nacreous foliated debris (threshold 2) of oysters (Magallana and Ostrea) behave like the first group of species (values within the envelope, close to Scrobicularia), while the chalky debris (threshold 1) show low $\tau_{0 \mathrm{cr}}$, similar to Anomia. Debris derived from Mytilus shells shows more variable results, with threshold values within the envelope for the largest $D_{\text {sieve }}$, and below the envelope for $D_{\text {sieve }}$ under $2 \mathrm{~mm}$. Non-dimensional representation of the $\tau_{0 \text { cr }}$ can be found in the Shields diagram reported in the Supporting Information.

\section{Equivalent roughness length}

Values of $\mathrm{k}_{\mathrm{s}}$, calculated from Eqs 5 and 6 (depending on $\mathrm{Re}^{*}$ ), and the dispersion of values, increase with $D_{\text {sieve }}$ (Fig. 9). No clear influence of the species on $k_{s}$ can be observed. Considering the mean values, $k_{s}$ is in the range of 1 to 3 $D_{\text {sieve }}$. Based on flume and field data compilation, Van Rijn (1993) shows that $k_{s}$ is in the range of 1 to $10 D_{90}$, and more commonly between 2 and $3 \mathrm{D}_{90}$ for non-moveable plane beds in a clear water flume. Weill et al. (2010) found the relation $k_{s}=2,56 \quad D_{\text {sieve }}$ with data acquired with sieved bioclastic sand. Here, the data correlation ( $k_{s}$ versus $\left.D_{\text {sieve }}\right)$ is in good agreement with the previous studies.

\section{DISCUSSION}

Bioclastic particles derived from the different mollusc species show non-negligible differences in specific gravity and shape, which can be partly explained by the structure of the shells and the mineralogical composition, as discussed in literature by Kennedy et al. (1969) and (Eyster, 1986). Among the studied species, shells made of aragonite ( $d$ ca 2.9 to 3.0 ) are the densest and more massive in structure, and include Crepidula, Cerastoderma and Ruditapes. Scrobicularia is composed of aragonite, but its thin and platy shells produce lighter debris. Mytilus shells are composed of aragonite and compact folia of calcite, and produce debris similar to that derived from Scrobicularia. Anomia shells are entirely composed of calcite ( $d$ ca $2 \cdot 6$ to $2 \cdot 8$ ) in thin sheets, producing extremely light micalike flakes when broken. Oyster shells (Ostrea and Magallana) are also made of calcite but feature an interstratified structure specific to the Ostreoidea superfamily: Micro-crystalline irregular calcite (amorphous and chalky in appearance) of very low specific gravity is interlayered with foliated calcite sheets (Orton \& Amirthalingam, 1927; Carter \& Clark, 1985), creating more or less hollow chambers, which perform a role that has not been deciphered yet (Lee et al., 2011; Dauphin et al., 2013). 

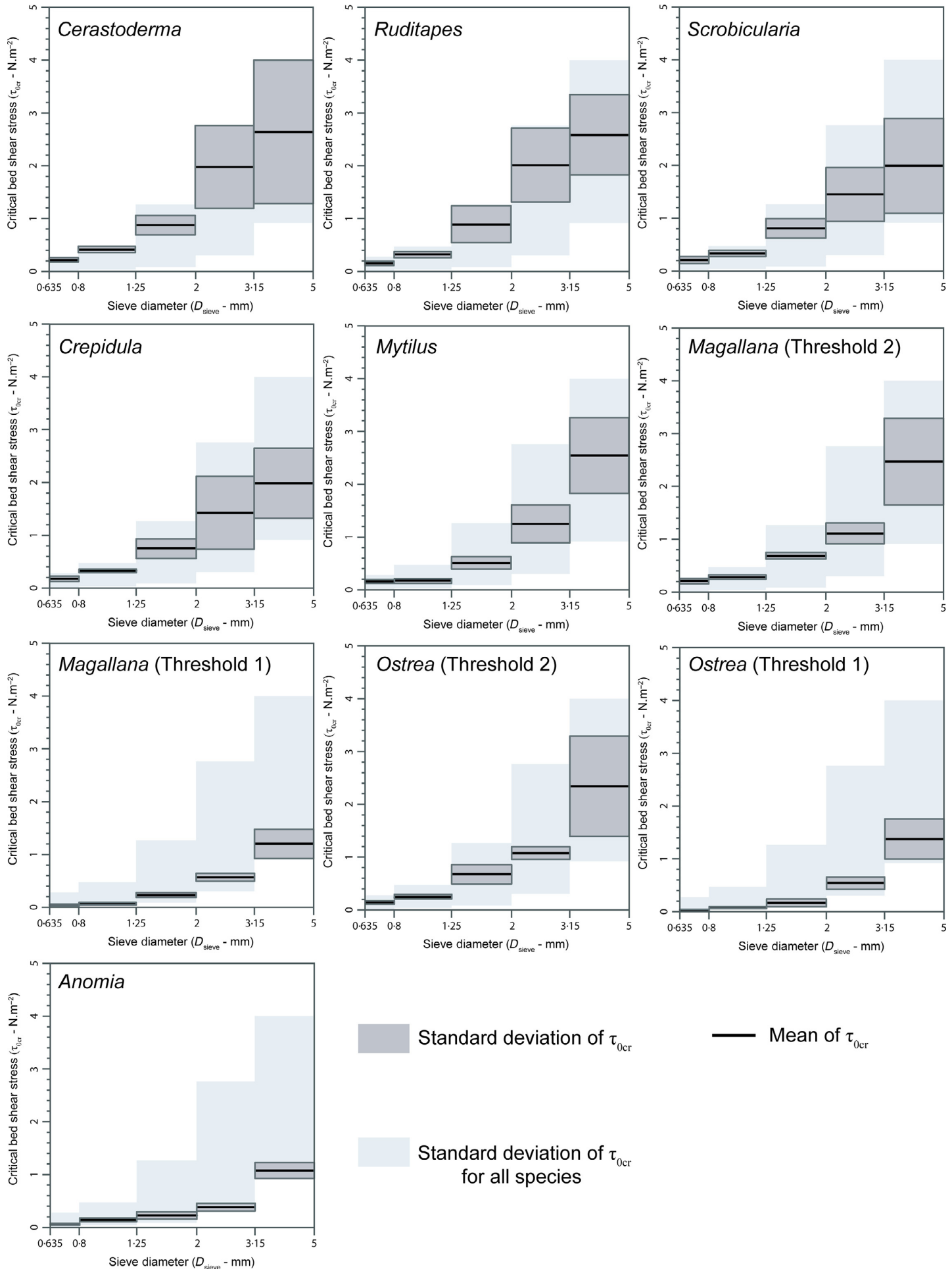

Standard deviation of $\tau_{0 \mathrm{cr}}$

Mean of $\tau_{0 \mathrm{cr}}$

Standard deviation of $\tau_{0 \mathrm{cr}}$ for all species

Fig. 7. Critical bottom shear stress as a function of sieve diameter for each species. The black line and the grey envelope are the mean and the standard deviation, respectively, of $\tau_{0 \mathrm{cr}}$ values obtained from several experiment replicates. The blue envelope represents the standard deviation of $\tau_{0 \mathrm{cr}}$ values of all species taken together.

All species, except oysters, have shells with a density $>2 \cdot 6$, close to that of calcite and aragonite. The lowest density of Magallana and
Ostrea shells is due to the presence of a very low density chalky calcite component. Oyster debris sampled from the field is essentially 


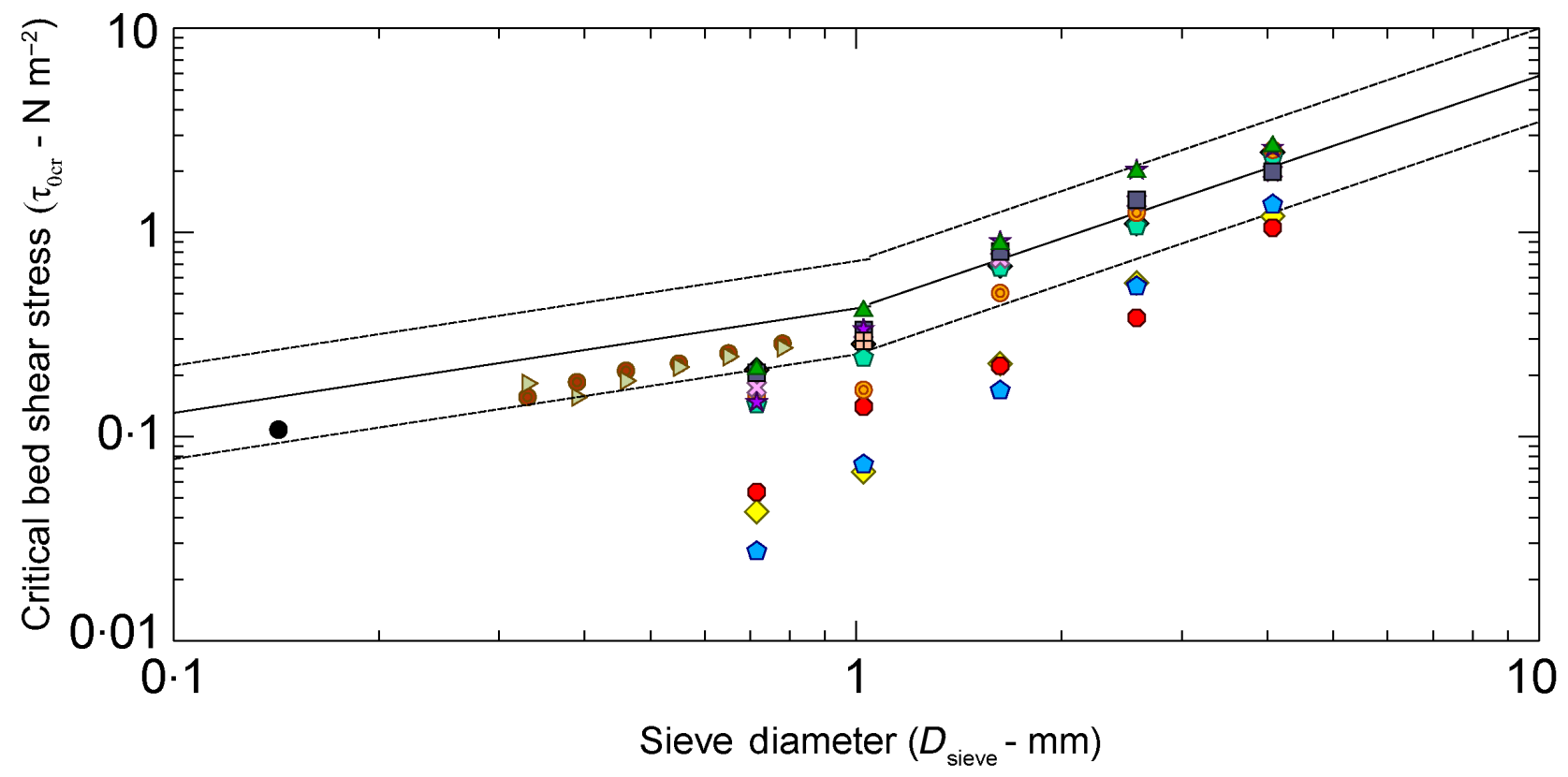

$\begin{array}{llll}\triangle \text { Cerastoderma } & \odot & \text { Mytilus } \\ \star & \text { Ruditapes } & \diamond & \text { Magallana (threshold 2) } \\ \square & \text { Scrobicularia } & \diamond & \text { Ostrea (threshold 2) } \\ \approx & \text { Crepidula } & \diamond & \text { Magallana (threshold 1) }\end{array}$

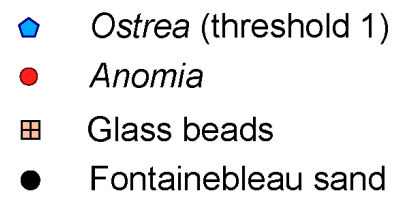

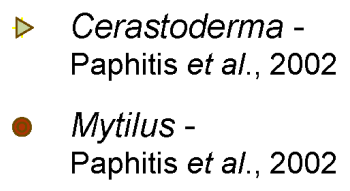

Fig. 8. Critical bottom shear stress as a function of the sieve diameter for each mollusc species, for well-sorted fine-grained quartz sand and for glass beads used for validation. The solid and dashed lines represent the empirical threshold curve and envelope, respectively, derived by Paphitis (2001) from a large amount of experimental data using well-sorted siliciclastic sands. Experimental data on Cerastoderma and Mytilus shell fragments from Paphitis et al. (2002) are reported as well.

made of foliated calcite. Chalky debris is rarely found, but can sometimes be attached to foliated sheets. This porous chalky matter is more likely to be prone to transport and erosion.

Settling velocities and critical bed shear stress measurements confirm the results obtained by Weill et al. (2010) on sieved samples of a natural mixture of mollusc shell debris. It also extends to other species the first results of Paphitis et al. (2002) on the comparison between Mytilus and Cerastoderma (Fig. 8). The interspecific differences of hydrodynamic behaviour can be attributed to some extent to differences of shell density and structure, because the same gradation between species is observed for $w_{s}, \tau_{0 \mathrm{cr}}$ and shell specific gravity. Debris derived from shell species with high density and a compact structure settles faster and is more resistant to flow. Debris derived from shell species with lower density and a foliated structure has lower $\mathrm{w}_{\mathrm{s}}$ and $\tau_{0 \mathrm{cr}}$. Compared to compact and dense debris, these particles are easier to move and should be transported longer distances prior to sedimentation, explaining sorting processes in natural environments.

It appears that the interspecific differences of $\tau_{\text {Ocr }}$ increases for smaller $D_{\text {sieve }}$, and two groups of species with distinctive behaviours can be identified (Fig. 8). Debris derived from species producing massive aragonitic shells (Cerastoderma, Ruditapes, Scrobicularia and Crepidula), as well as debris from the foliated calcite part of oyster shells have very similar $\tau_{0 \mathrm{cr}}$, and quite accurately follow the threshold envelope determined from classic quartz sand. However, foliated calcite debris of oyster shells has slightly lower $\tau_{0 \text { cr }}$ compared to debris from massive aragonite shells. Debris derived from foliated Anomia shells and from the chalky component of oyster shells (Ostrea and Magallana) present much smaller $\tau_{\text {ocr }}$ for small $D_{\text {sieve }}$, the difference with the first group decreasing with increasing $D_{\text {sieve. }}$ The thickness of debris derived from massive species corresponds roughly to the thickness of the shell. The breakage process favours a reduction of the 


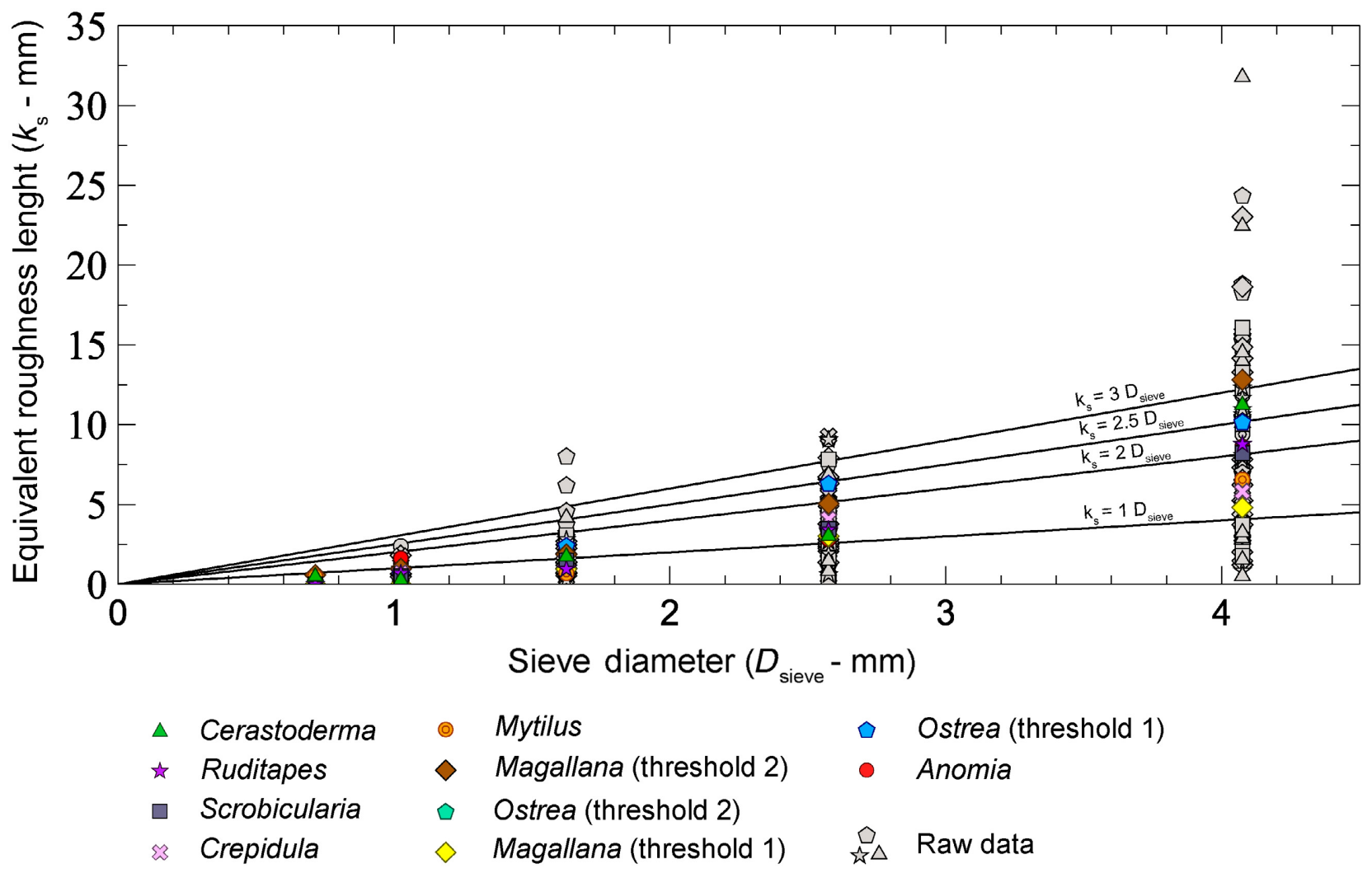

Fig. 9. Equivalent roughness length as a function of sieve diameter for each species. Grey symbols are raw replicate data; coloured symbols are mean values. For the sake of comparison, $k_{\mathrm{s}}$ is also drawn as linear functions of $D_{\text {sieve }}$ (solid black lines).

large and intermediate lengths of the debris, while its thickness remains unchanged. Thus, the shape of the bioclastic particles will tend towards an equant block with decreasing $D_{\text {sieve }}$. For debris derived from foliated Anomia shells, the breakage process produces a reduction of the large and intermediate lengths, but mainly leads to a reduction of the particle thickness by delaminating the calcite sheets. Thus, for similar large and intermediate lengths (and thus similar $D_{\text {sieve }}$ ), debris derived from foliated Anomia shells will be thinner and lighter than debris derived from massive aragonitic shells, or from more resistant oyster shells. Concerning the chalky part of oyster shells, although their shape is blocky, the very low specific density of this porous micro-crystalline material explains the low $\tau_{\text {ocr. }}$. These particle characteristics might explain the divergence of $\tau_{0 \text { cr }}$ between the two species groups for small particle diameters.

Settling experiments revealed that bioclastic particles have low $w_{s}$ compared with glass beads or quartz grains (Fig. 6; Paphitis et al., 2002; Weill et al., 2010) which can be attributed to the flat shape of the shell debris. However, in terms of threshold of motion, bioclastic particles are within or close to the envelope of threshold defined for siliciclastic sediments. Collins \& Rigler (1982) showed that a relationship exists between $\tau_{0 \mathrm{cr}}$ and the $w_{s}$ using terrigenous particles (Fig. 10; quartz grains, heavy minerals) and finer quartz data from White (1970), following the form:

$$
\tau_{0 c r}=\mathrm{a} w_{s}^{\mathrm{b}}
$$

where a and b are constants equal to 1.24 and $0 \cdot 33$, respectively. This suggests that $w_{s}$ encompasses more critical parameters influencing the particle hydrodynamic behaviour (including weight, shape and roughness) than does a simple grain diameter derived from sieve analysis. This concept has been used to introduce the movability number (Mn), which is the ratio between $u_{*}$ and $w_{s}$ (Eq. 8). It is used as an alternative to $\theta$ (Komar \& Clemens, 1986; Beheshti \& Ataie-Ashtiani, 2008; Armitage \& Rooseboom, 2010). Paphitis et al. (2002) and Weill et al. (2010) applied Mn to bioclastic particles and found 

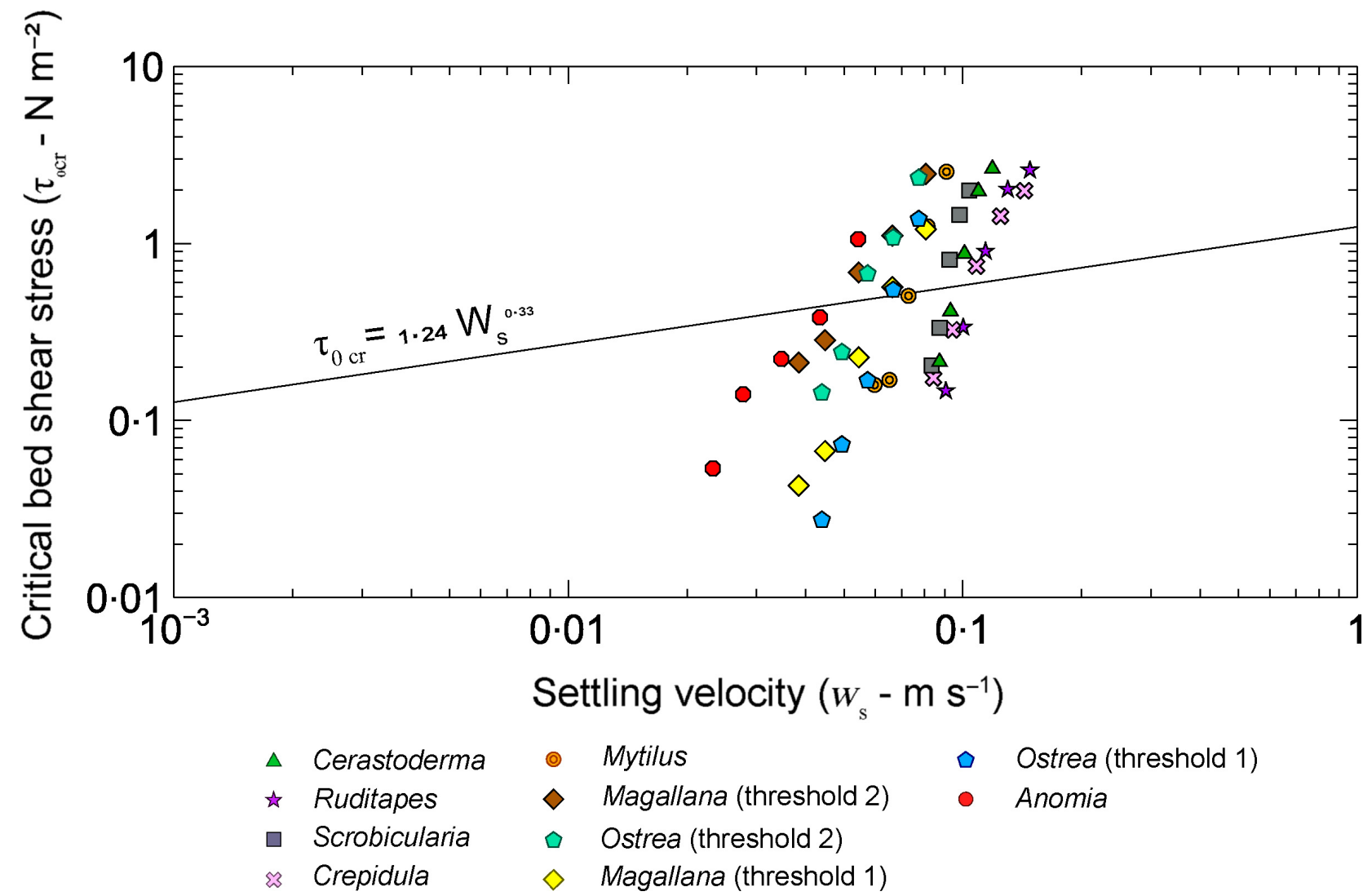

Fig. 10. Critical bottom shear stress as a function of grain settling velocity. The empirical relationship from Collins \& Rigler (1982) is reported on the graph (black line).

contradictory results. Paphitis et al. (2002) found on fine-grained debris of Mytilus and Cerastoderma that data plot closer and with less disparity to the empirical prediction envelope for quartz grains when $\mathrm{Mn}$ is used. Weill et al. (2010) showed that data obtained with coarse bioclastic particles systematically plot above the prediction curve for quartz sand, suggesting that the low $w_{S}$ of shell debris is not a relevant parameter to estimate sediment transport initiation.

Critical bed shear stress values from the present study are plotted as a function of $w_{s}$, and compared to the empirical curve defined by Collins \& Rigler (1982) (Fig. 10). Once again, interspecific differences appear in the data. All species follow a power law (linear trend in the log-log plot), but with significant offset on the settling velocity axis. Again, the differences can be attributed to the structure, density and shape of the bioclastic particles, with a distinctive group composed of species with massive aragonitic shells, and another group, more scattered, comprising foliated and interstratified shells. Globally, bioclastic particles follow a very different trend compared to terrigenous particles, with large variations of $\tau_{\text {ocr }}$ over a relatively narrow range of $w_{s}$. All species follow the same law of Collins \& Rigler (1982), but with very different coefficients (Eq. 9). The slope coefficient $(a)$ ranges between $1.3 \times 10^{-4}$ and $10^{-11}$ and the coefficient $\mathrm{b}$ ranges between $3 \cdot 2$ and $10 \cdot 8$ (Table 3).

The complex relationship between $\tau_{0 \mathrm{cr}}$ and $w_{s}$ for bioclastic particles also appears in the movability diagram where Mn (Eq. 8) is plotted as a function of $\mathrm{Re}^{*}$ (Fig. 11). First, the disparity between mollusc species is slightly reduced. This suggests that differences of $\tau_{\text {ocr }}$ between species might be somehow explained by differences of particle density and shape which influence $w_{S}$. Second, data plot almost systematically above the envelope defined for quartz sand, except for the lowest $\mathrm{Re}^{*}(<10)$. Compared to siliciclastic particles, coarse shell debris shows similar resistance to the flow (see $\tau_{0 \mathrm{cr}}$ values; Fig. 8), but have much slower $w_{s}$ (Fig. 6) due to their platy shape which increases the drag forces. This produces high Mn compared to the empirical envelope for quartz sand.

For low $\mathrm{Re}^{*}$, values of $\mathrm{Mn}$ that fall within or below the empirical curve for quartz sand can be 

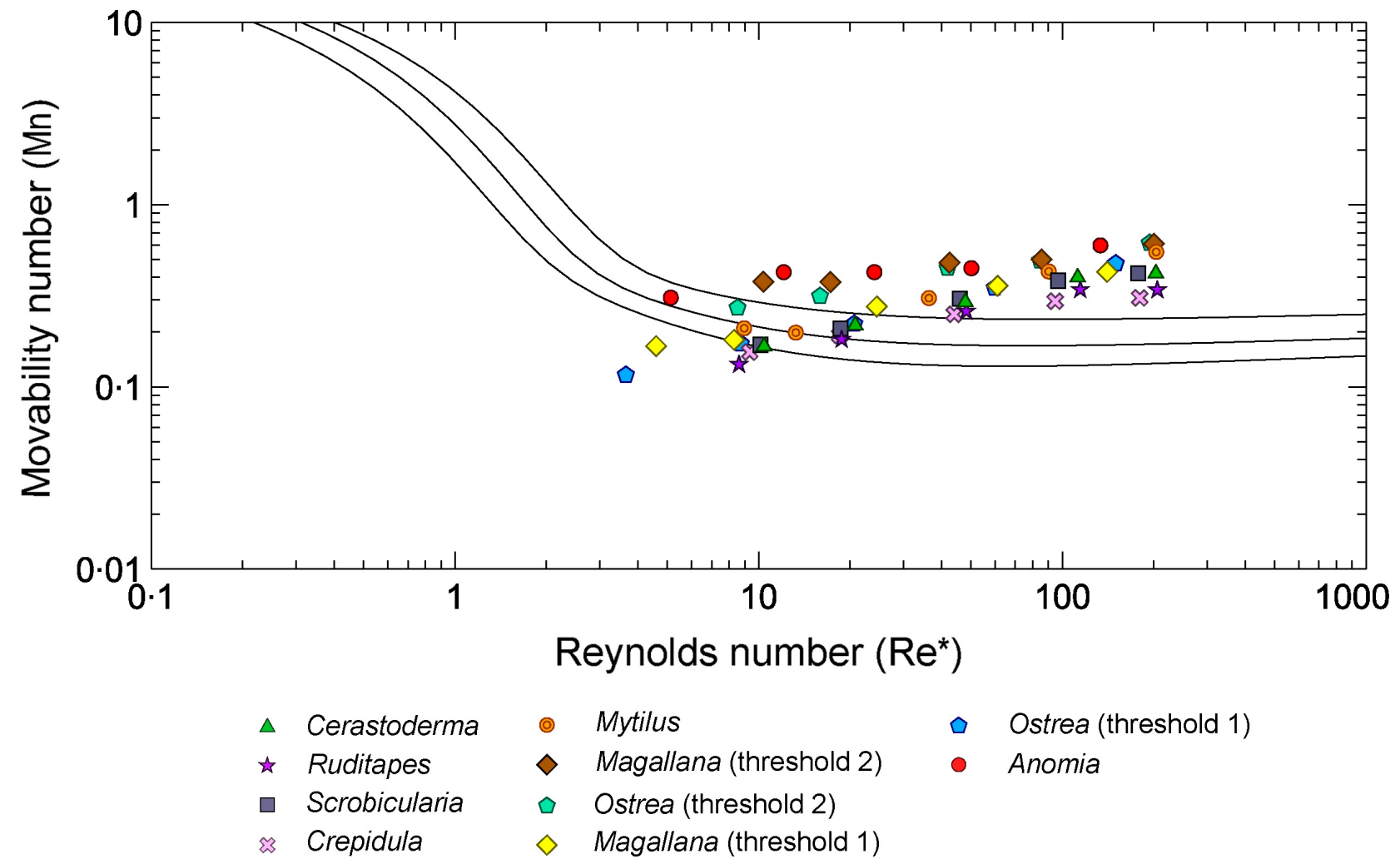

- Ostrea (threshold 1)

- Anomia

Fig. 11. Movability number as a function of grain Reynolds number. Empirical curves and envelope for siliciclastic sediments are redrawn from Paphitis (2001).

explained again by a contribution of both particle shape and density. For small $D_{\text {sieve, }}$, the large and intermediate lengths tend to be closer to the thickness of the particle, resulting in a blockier shape. These particles have values of $w_{\mathrm{s}}$ closer to those of sub-rounded quartz grains. Moreover, shell species with an aragonitic composition (Crepidula, Cerastoderma, Ruditapes and Scrobicularia) have densities greater than the density of quartz (Table 1), further increasing $w_{S}$, and decreasing $\mathrm{Mn}$. In comparison, debris from Anomia have high Mn because the particles keep their flake-like shape at small $D_{\text {sieve, }}$, resulting in very low $w_{s}$.

Due to the flat shape, shell debris has low to very low $w_{s}$ compared to spheres of similar $D_{\text {sieve }}$. The trajectory of a settling particle can be complex, sometimes chaotic (Maiklem, 1968; Field et al., 1997), thus increasing the path length. Settling velocity is critical to understand the behaviour of bioclastic particles once transport is initiated. However, this flat shape also provides stability to particles resting on a sediment bed, either by interlocking effects between particles, or by making particle rolling more difficult. This may explain why studied bioclastic particles have threshold of motion similar to siliciclastic sediments. These antinomic consequences of the flat shape on shell debris hydrodynamic behaviour prevents the use of $w_{s}$ or Mn to characterize the initiation of motion of such carbonate sediment. Based on the experimental results of this study, it appears that $w_{S}$ is more sensitive to interspecific differences in terms of shell density, structure and shape than the threshold of motion.

In the fossil record or in modern depositional environments, it is common to observe natural segregation between bioclastic and siliciclastic sediments, for example in tide-dominated environments where bedforms develop and evolve under varying current velocity (Longhitano, 2011; Chiarella \& Longhitano, 2012; Longhitano et al., 2012). Generally, bioclastic laminae are attributed to depositional processes under lower energy conditions rather than during the deposition of siliciclastic laminae, as settling velocities of bioclastic particles are much smaller than settling velocities of the siliciclastic sand fraction. However, this study clearly shows that the low settling velocities of mollusc shell debris do not imply low thresholds of motion, which are close 
to thresholds of motion for quartz sand. It is thus important for interpretation of palaeoenvironments to make the distinction between the initiation of motion of bioclastic particles (related to $\tau_{0 \mathrm{cr}}$ ) and the ability of bioclastic particles to be transported once the motion is initiated (related to $w_{s}$ ). Sorting processes and sediment fluxes in bioclastic-siliciclastic sediment mixtures are still to be investigated in future experiments.

\section{CONCLUSIONS}

Settling velocities and bed shear stress values have been experimentally determined for coarse bioclastic debris of eight mollusc species representative of temperate to cold water coastal environments. The results obtained led to the following conclusions:

1 Significant differences have been found between species, both in terms of settling velocity and threshold of motion. The interspecific differences in settling velocity are coherent with those observed in threshold of motion (particles that settle faster show higher resistance to the flow).

2 Shell density and structure account primarily for the diversity of hydrodynamic behaviour observed. Particle shape is also a critical parameter, its influence increasing with increasing particle diameter. Mollusc shells, according to their composition (calcite and/or aragonite), have either compact, foliated or a more complex structure. Debris derived from foliated shells (for example, Anomia) moves earlier and settles slower than debris derived from compact shells (for example, Scrobicularia and Crepidula). Oyster shells, due to their complex structure (chalky porous matter interstratified with foliated layers), produce debris with very distinct behaviours.

3 Considering threshold of motion only, debris from species with dense compact shells behave like siliciclastic particles. Debris from foliated (or chalky) shells show lower critical shear stress values. No species were found to produce debris that was more difficult to move than siliclastic particles.

4 Movability number values calculated for shell debris plot above the empirical envelope for siliciclastic sediment. If entrainment thresholds are similar between bioclastic and siliciclastic sediments, bioclastic particles have significantly lower settling velocities, resulting in over-estimated values of movability numbers. Unlike for siliciclastic sands, the settling velocity is not an appropriate parameter to predict threshold of motion of shell debris. However, settling velocity is thought to have a significant influence once sediment transport is initiated.

The differences in hydrodynamic behaviour of shell debris determined between species, as well as with siliciclastic grains, should be considered to better model sediment sorting, transport and depositional processes that characterize modern bioclastic coastal environments. These results can also help in interpreting shelly coastal rock records. For further understanding of bioclastic sediment behaviour, flume experiments under the combined action of waves and currents should be conducted.

\section{ACKNOWLEDGEMENTS}

This study is part of Alissia Rieux's PhD work, funded by the Normandy Regional Council and the Ministry for the Ecological and Inclusive Transition (DDTM 35), in the frame of the research project Sédibaie. We thank Julie Gonand (M2C Lab, Rouen) who took the scanning electron microscopy images. We are grateful to the Chief Editor, Peir Pufahl, the Associate Editor, Subhasish Dey and to the journal reviewers (Stephan Jorry and an anonymous reviewer) for their helpful comments which improved an early version of the manuscript.

\section{NOTATION}

\begin{tabular}{ll}
\hline$C_{D}$ & Drag coefficient \\
$D_{\text {sieve }}$ & Particle diameter \\
$G$ & Acceleration due to gravity \\
$k_{s}$ & Equivalent roughness length \\
$\mathrm{Mn}$ & Movability number \\
$\operatorname{Re}{ }_{*}$ & Grain Reynolds number \\
$u$ & Current velocity profile \\
$u_{*}$ & Critical shear velocity \\
$w_{S}$ & Settling velocity \\
$z$ & Streamwise mean velocity \\
$z_{0}$ & Zero-level velocity \\
$v$ & Kinematic viscosity of the water \\
$\kappa$ & von Kármán constant \\
$\tau_{0 \mathrm{cr}}$ & Critical bottom shear stress \\
$\rho$ & Fluid density \\
$\rho_{\mathrm{s}}$ & Sediment density \\
$\theta$ & Shields entrainment function \\
\end{tabular}




\section{REFERENCES}

Allen, J.R.L. (1984) Experiments on the settling, overturning and entrainment of bivalve shells and related models. Sedimentology, 31, 227-250.

Armitage, N. and Rooseboom, A. (2010) The link between movability number and incipient motion in river sediments. Water SA, 36, 89-96.

Beheshti, A.A. and Ataie-Ashtiani, B. (2008) Analysis of threshold and incipient conditions for sediment movement. Coast. Eng., 55, 423-430.

Beukema, J.J., Cadée, G.C. and Hummel, H. (1983) Differential variability in time and space of numbers in suspension and deposit feeding benthic species in a tidal flat area. In: Oceanologica Acta, 1983. Proceedings 17th European Marine Biology Symposium, Brest, France, 27 September-1 October, 1982, 21-26.

Biron, P.M., Robson, C., Lapointe, M.F. and Gaskin, S.J. (2004) Comparing different methods of bed shear stress estimates in simple and complex flow fields. Earth Surf. Proc. Land., 29, 1403-1415.

Bonnot-Courtois, C., Fournier, J. and Dréau, A. (2004) Recent morphodynamics of shell banks in the western part of the Bay of Mont-Saint-Michel (France)/ Morphodynamique actuelle des bancs coquilliers dans la partie occidentale de la baie du Mont-Saint-Michel (France). Géomorphol. Rel. Proces. Environ., 10, 65-79.

Braithwaite, C.J.R. (1973) Settling behaviour related to sieve analysis of skeletal sands. Sedimentology, 20, 251-262.

Brand, A., Noss, C., Dinkel, C. and Holzner, M. (2016) Highresolution measurements of turbulent flow close to the sediment-water interface using a bistatic acoustic profiler. J. Atmos. Ocean Tech., 33, 769-788.

Cadée, G.C. (1994) Eider, Shelduck and other predators, the main producers of shell fragments in the Wadden Sea: Palaeoecological implications. Palaeontology, 37, 181-202.

Carter, J. and Clark, G.I. (1985) Classification and phylogenetic significance of molluscan shell microstructures. In: Notes for a Short Course (Ed. T.W. Broadhead), Studies in Geology 13, 50-71.

Chiarella, D. and Longhitano, S.H. (2012) Distinguishing depositional environments in shallow-water mixed, biosiliciclastic deposits on the basis of the degree of heterolithic segregation (Gelasian, southern Italy). $J$. Sediment. Res., 82, 969-990.

Collins, M.B. and Rigler, J.K. (1982) The use of settling velocity in defining the initiation of motion of heavy mineral grains, under unidirectional flow. Sedimentology, 29, 419-426.

Craig, R.G., Loadman, C., Clement, B., Rusello, P.J. and Siegel, E. (2011) Characterization and testing of a new bistatic profiling acoustic Doppler velocimeter: The Vectrino-II. Current, Waves and Turbulence Measurements (CWTM), 2011 IEEE/OES 10th, 246-252.

Dauphin, Y., Ball, A.D., Castillo-Michel, H., Chevallard, C., Cuif, J.P., Farre, B., Pouvreau, S. and Salomé, M. (2013) In situ distribution and characterization of the organic content of the oyster shell Crassostrea gigas (Mollusca, Bivalvia). Micron, 44, 373-383.

Driscoll, E.G. (1967) Experimental field study of shell abrasion. J. Sediment. Petrol., 37, 1117-1123.

Eyster, L.S. (1986) Shell inorganic composition and onset of shell mineralization during bivalve and gastropod embryogenesis. Biol. Bull., 170, 211-231.
Field, S.B., Klaus, M., Moore, M.G. and Nori, F. (1997) Chaotic dynamics of falling disks. Nature, 388, 252-254.

Flemming, B.W. (2017) Particle shape-controlled sorting and transport behaviour of mixed siliciclastic/bioclastic sediments in a mesotidal lagoon, South Africa. Geo-Mar. Lett., 37, 397-410.

Gibbs, R.J., Matthews, M.D. and Link, D.A. (1971) The relationship between sphere size and settling velocity. $J$. Sediment. Res., 41, 7-18.

Gorzelak, P., Salamon, M.A., Trzesiok, D. and Niedźwiedzki, R. (2013) Drill holes and predation traces versus abrasion-induced artifacts revealed by tumbling experiments. PLoS One, 8, e58528.

Halpern, B.S., Wallbridge, S., Selkoe, K.A., Kappel, C.V., Micheli, F., D’Agrosa, C., Bruno, J.F., Casey, K.S., Ebert, C., Fox, H.E., Fujita, R., Heinemann, D., Lenihan, H.S., Madin, E.M., Perry, M.T., Selig, E.R., Spalding, M., Steneck, R. and Watson, R. (2008) A global map of human impact on marine ecosystems. Science, 319, 948952.

Hewitt, J.E., Ellis, J.I. and Thrush, S.F. (2016) Multiple stressors, nonlinear effects and the implications of climate change impacts on marine coastal ecosystems. Glob. Change Biol., 22, 2665-2675.

Holme, N.A. (1961) The bottom fauna of the English Channel. J. Mar. Biol. Assoc. U.K., 41, 397-461.

James, N.P. and Clarke, J.A.D. (1997) Cool-Water Carbonates. SEPM Special Publication 56, Tulsa, Oklahoma, 440 pp.

Janke, N.C. (1965) Empirical formula for velocities and Reynolds' numbers of single, settling spheres. J. Sediment. Res., 35, 749-750.

Jorry, S.J., Hasler, C.-A. and Davaud, E. (2006) Hydrodynamic behaviour of Nummulites: implications for depositional models. Facies, 52, 221-235.

Joshi, S., Duffy, G.P. and Brown, C. (2014) Settling velocity and grain shape of maerl biogenic gravel. J. Sediment. Res., 84, 718-727.

Joshi, S., Duffy, G.P. and Brown, C. (2017) Critical bed shear stress and threshold of motion of maerl biogenic gravel. Estuar. Coast. Shelf Sci., 194, 128-142.

Kench, P.S. and McLean, R.F. (1996) Hydraulic characteristics of bioclastic deposits: new possibilities for environmental interpretation using settling velocity fractions. Sedimentology, 43, 561-570.

Kench, P.S. and McLean, R.F. (1997) A comparison of settling and sieve techniques for the analysis of bioclastic sediments. Sed. Geol., 109, 111-119.

Kennedy, W.J., Taylor, J.D. and Hall, A. (1969) Environmental and biological controls on bivalve shell mineralogy. Biol. Rev., 44, 499-530.

Kidwell, S.M. (2013) Time-averaging and fidelity of modern death assemblages: building a taphonomic foundation for conservation palaeobiology. Palaeontology, 56, 487-522.

Koca, K., Noss, C., Anlanger, C., Brand, A. and Lorke, A. (2017) Performance of the Vectrino Profiler at the sediment-water interface. J. Hydraul. Res., 55, 573-581.

Komar, P.D. and Clemens, K.E. (1986) The relationship between a grain's settling velocity and threshold of motion under unidirectional currents. J. Sediment. Petrol., 56, 258-266.

Komar, P.D. and Cui, B. (1984) The analysis of grain-size measurements by sieving and settling-tube techniques. $J$. Sediment. Res., 54, 603-614. 
Komar, P.D. and Reimers, C.E. (1978) Grain shape effects on settling rates. J. Geol., 86, 193-209.

Kramer, H. (1935) Sand mixtures and sand movement in fluvial models. Proc. Am. Soc. Civil Eng. Trans. Am. Soc., 100, 798-878.

Lee, S.-W., Jang, Y.-N., Ryu, K.-W., Chae, S.-C., Lee, Y.-H. and Jeon, C.-W. (2011) Mechanical characteristics and morphological effect of complex crossed structure in biomaterials: Fracture mechanics and microstructure of chalky layer in oyster shell. Micron, 42, 60-70.

Liu, H.-K. (1957) Mechanics of sediment-ripple formation. J. Hydraul. Div. ASCE, 83, 23.

Longhitano, S.G. (2011) The record of tidal cycles in mixed silici-bioclastic deposits: examples from small PlioPleistocene peripheral basins of the microtidal Central Mediterranean Sea. Sedimentology, 58, 691-719.

Longhitano, S.G., Chiarella, D., Di Stefano, A., Messina, C., Sabato, L. and Tropeano, M. (2012) Tidal signatures in Neogene to Quaternary mixed deposits of southern Italy straits and bays. Sed. Geol., 279, 74-96.

Macvicar, B.J., Dilling, S., Lacey, R.W.J. and Hipel, K. (2014) A quality analysis of the Vectrino II instrument using a new open-source MATLAB toolbox and 2D ARMA models to detect and replace spikes. In: Proceedings of the International Conference on Fluvial Hydraulics, RIVER FLOW (Eds A.J. Schleiss, G. de Cesare, M.J. Franca and M. Pfister), pp. 1951-1959. CRC Press, Lausanne, Switzerland.

Maiklem, W.R. (1968) Some hydraulic properties of bioclastic carbonate grains. Sedimentology, 10, 101-109.

McNown, J.S. and Malaika, J. (1950) Effects of particle shape on settling velocity at low Reynolds numbers. Trans. Am. Geophys. Union, 31, 74-82.

Miller, M.C., McCave, I.N. and Komar, P.D. (1977) Threshold of sediment motion under unidirectional currents. Sedimentology, 24, 507-527.

Newell, A.J., Gower, D.J., Benton, M.J. and Tverdokhlebov, V.P. (2007) Bedload abrasion and the in situ fragmentation of bivalve shells. Sedimentology, 54, 835-845.

Nikuradse, J. (1933) Strömungsgesetze in rauhenRohren (Laws of Flow in Rough Pipes). National Advisory Committee for Aeronautics, Washington, DC.

NortekAs. Vectrino profiler. Available at: http://www.nortekas.com/en/products/velocimeters/vectrino-ii.

Orton, J. and Amirthalingam, C. (1927) Notes on shelldepositions in oysters. J. Mar. Biol. Assoc. U.K., 14, 935-954.

Oseen, C.W. (1927) Neuere Methoden und Ergebnisse in der Hydrodynamik. Akademische Verlagsgesellschaft.m.b.h, Leipzig, 337 pp.

Paphitis, D. (2001) Sediment movement under unidirectional flows: an assessment of empirical threshold curves. Coast. Eng., 43, 227-245.

Paphitis, D. and Collins, M.B. (2005) Sand grain threshold, in relation to bed "stress history": an experimental study. Sedimentology, 52, 827-838.

Paphitis, D., Collins, M.B., Nash, L.A. and Wallbridge, S. (2002) Settling velocities and entrainment thresholds of biogenic sands (shell fragments) under unidirectional flow. Sedimentology, 49, 211-225.

Prager, E.J., Southard, J.B. and Vivoni-Gallart, E.R. (1996) Experiments on the entrainment threshold of well-sorted and poorly sorted carbonate sands. Sedimentology, 43, 3340.

Rubey, W.W. (1933) Settling velocity of gravel, sand, and silt particles. Am. J. Sci., 25, 325-338.
Ruonan, B., Liekai, C., Xingkui, W. and Danxun, L. (2016) Comparison of ADV and PIV measurements in open channel flows. Procedia Eng., 154, 995-1001.

Rusello, P.J. and Allard, M.P. (2012) Near boundary measurements with a profiling acoustic Doppler velocimeter. Hydraulic Measurement and Experimental Methods 2012 Conference, Snowbird, UT, USA, 12-15 August, 2012.

Sengupta, S. and Veenstra, H.J. (1968) On sieving and settling techniques for sand analysis. Sedimentology, 11, 83-98.

Shields, A. (1936) Application of similarity principles and turbulence research to bed-load movement (English translation of an original German manuscript). Hydrodynamics Laboratory, California Institute of Technology, Pasadena, CA.

Simões, F.J.M. (2014) Shear velocity criterion for incipient motion of sediment. Water Sci. Eng., 7, 183-193.

Smith, D.A. and Cheung, K.F. (2002) Empirical relationships for grain size parameters of calcareous sand on Oahu, Hawaii. J. Coastal Res., 18, 82-93.

Smith, D.A. and Cheung, K.F. (2003) Settling characteristics of calcareous sand. J. Hydraul. Eng., 129, 479-483.

Smith, D.A. and Cheung, K.F. (2004) Initiation of motion of calcareous sand. J. Hydraul. Eng., 130, 467-472.

Stokes, G.G. (1851) On the Effect of the Internal Friction of Fluids on the Motion of Pendulums. Pitt Press, Cambridge.

Thorin, S., Radureau, A., Feunteun, E. and Lefeuvre, J.-C. (2001) Preliminary results on a high east-west gradient in the macrozoobenthic community structure of the macrotidal Mont Saint-Michel bay. Cont. Shelf Res., 21, 2167-2183.

Thorson, G. (1957) Bottom communities (sublittoral or shallow shelf). In: Treatise on Marine Ecology and Palaeoecology. Geological Society of America. (Ed. J.W. Hedgpeth), pp. 461-534. Geological Society of America, New York.

Van Rijn, L. (1993) Principles of Sediment Transport in Rivers, Estuaries and Coastal Seas. Aqua Publications, Amsterdam, The Netherlands, 690 pp.

Weill, P., Mouazé, D., Tessier, B. and Brun-Cottan, J.-C. (2010) Hydrodynamic behaviour of coarse bioclastic sand from shelly cheniers. Earth Surf. Proc. Land., 35, 1642-1654.

Weill, P., Tessier, B., Mouazé, D., Bonnot-Courtois, C. and Norgeot, C. (2012) Shelly cheniers on a modern macrotidal flat (Mont-Saint-Michel bay, France) - Internal architecture revealed by ground-penetrating radar. Sed. Geol., 279, 173-186.

Weill, P., Mouazé, D. and Tessier, B. (2013) Internal architecture and evolution of bioclastic beach ridges in a megatidal chenier plain: Field data and wave flume experiment. Sedimentology, 60, 1213-1230.

Wengrove, M.E. and Foster, D.L. (2014) Field evidence of the viscous sublayer in a tidally forced developing boundary layer. Geophys. Res. Lett., 41, 5084-5090.

White, S.J. (1970) Plane bed thresholds of fine grained sediments. Nature, 228, 152-153.

Wilkinson, R.H. (1983) A method for evaluating statistical errors associated with logarithmic velocity profiles. GeoMarine Lett., 3, 49-52.

Zuschin, M., Stachowitsch, M. and Stanton, R.J. (2003) Patterns and processes of shell fragmentation in modern and ancient environments. Earth-Sci. Rev., 63, 33-82.

Manuscript received 2 February 2018; revision accepted 10 July 2018 


\section{A. Rieux et al.}

\section{Supporting Information}

Additional information may be found online in the Supporting Information section at the end of the article.

Fig. S1. Shields entrainment function as a function of grain Reynolds number. Shields curves have been redrawn from Paphitis (2001).
Fig. S2. Comparison of Shields entrainment function for Cerastoderma and Mytilus obtained in the present study with experimental data of Paphitis et al. (2002).

Table S1. Errors (propagated from velocity profiles regressions) on experimental parameters at the entrainment threshold.

Table S2. Precision (standard deviation) of experimental parameters at the entrainment threshold. 